
\title{
$\begin{array}{ll}\text { Research Square } & \text { They should not be considered conclusive, used to inform clinical practice, } \\ \text { or referenced by the media as validated information. }\end{array}$
}

\section{Revision of Immersaria and a New Lecanorine Genus in Lecideaceae (Lichenized Ascomycota, Lecanoromycetes)}

\author{
Congmiao Xie \\ Shandong Normal University \\ Li Song Wang \\ Kunming Institute of Botany \\ Zun Tian Zhao \\ Shandong Normal University \\ Yan Yun Zhang \\ Kunming Institute of Botany \\ Xin Yu Wang ( $\nabla$ wangxinyu@mail.kib.ac.cn ) \\ Kunming Institute of Botany \\ Lu Lu Zhang \\ Shandong Normal University
}

\section{Research}

Keywords: Taxonomy, Phylogeny, Generic classification, Lecanorine apothecia, Lichen, China

Posted Date: June 29th, 2021

DOI: https://doi.org/10.21203/rs.3.rs-645064/v1

License: (c) (i) This work is licensed under a Creative Commons Attribution 4.0 International License. Read Full License 


\section{Abstract}

The species Immersaria cupreoatra has repeatedly been reassigned between Bellemerea and Immersaria. This caused us to reconsider the relationships between Bellemerea and the lecanorine species of Immersaria, and to question the monophyly of Immersaria. Among 25 genera of the family Lecideaceae, most have lecideine apothecia, with the exception of Bellemerea and Koerberiella, which have lecanorine apothecia. According to previous classifications, Immersaria included species with both lecanorine and lecideine apothecia. A five-loci phylogenetic tree (nrlTS, nrLSU, RPB1, RPB2 and mtSSU) for Lecideaceae showed that Immersaria was split into two clades: firstly all the lecideine apothecia species, and secondly all the lecanorine apothecia species. The latter were closely related to the remaining lecanorine apothecia genera: Bellemerea and Koerberiella. Therefore, the genus concept of Immersaria was revised accordingly, and a new lecanorine genus Lecaimmeria was proposed. Furthermore, five new species for Immersaria, and seven new species and three new combinations for the new genus Lecaimmeria were proposed. Keys to Immersaria, the new genus Lecaimmeria and allied genera were provided.

\section{Introduction}

The lichen genus Immersaria Rambold \& Pietschmann (Rambold 1989) was originally constructed from the genus Lecidea Ach. in order to accommodate the species Immersaria athroocarpa (Ach.) Rambold \& Pletschmann. The genus Immersaria was characterized by its brown thallus with an epinecral layer, a pruinose margin and an amyloid medulla, immersed apothecia with a somewhat reduced proper margin and Porpidia-type asci with eight spores, halonate and simple ascospores (Rambold 1989). Subsequently, Calatayud and Rambold (1998) enlarged the scope of the genus by including the lecanorine species, I. mehadiana Calat. \& Rambold and I. cupreoatra (Nyl.) Calat. \& Rambold, based on morphological characters only. Currently, eight species of Immersaria are known worldwide (Lücking et al. 2017), three of which have lecanorine apothecia. Three of these species were previously reported from China (Hertel 1977, Zhang et al. 2015).

The genetic position of the species Immersaria cupreoatra (Nyl.) Calat. \& Rambold was repeatedly reassigned between Bellemerea Hafellner \& Cl. Roux (Clauzade and Roux 1984) and Immersaria (Calatayud and Rambold 1998). This caused us to reconsider the relationships between Bellemerea and the lecanorine species of Immersaria, and to question the monophyly of Immersaria. The family Lecideaceae Chevall originally included all the crustose lecideoid genera, but now only 25 genera have been retained. Most of these are monospecific genera or small genera with under five species (Fryday and Hertel 2014, McCune et al. 2017). The majority of genera in Lecideaceae have lecideine apothecia. Three exceptions are Bellemerea, Immersaria and Koerberiella Stein, which have lecanorine apothecia. Only Immersaria has both lecanorine and lecideine apothecia, according to previous circumscription (Calatayud and Rambold 1998, Valadbeigi et al. 2011). Calatayud and Rambold (1998) indicated that the presence of "two types of ascomata" represent different stages of ontogeny. However, there was no molecular evidence that could clarify the species-level phylogenetic relationships within Immersaria. In the two-loci phylogenetic tree of Buschbom and Mueller (2004), the lecideine species I. usberkica (Hertel) M. Barbero, Nav.-Ros. \& Cl. Roux were related to Lecidea tessellata Flörke. However, because only two loci of one lecideine species were included, their tree was insufficient to clarify the relationship of the lecanorine apothecia species in Immersaria.

In this study, a phylogenetic tree of Lecideaceae, based on five loci, was established in order to verify the monophyly of Immersaria. The results showed that Immersaria was split into two clades. One clade included all the lecideine apothecia species, was sister to Lecidea tessellata, L. auriculata Th. Fr., Cyclohymenia epilithica McCune \& M.J. Curtis and Porpidia albocaerulescens group. The second clade contained all the lecanorine apothecia species and was closely related to the rest of the lecanorine apothecia genera within this family: Bellemerea and Koerberiella. Therefore, the genus concept of Immersaria was revised, to retain only the species which had lecideine apothecia. The lecanorine species of Immersaria were excluded and proposed to belong to a new genus, Lecaimmeria C.M. Xie, Lu L. Zhang \& Li S. Wang. Furthermore, five new species for Immersaria, seven new species and three new combinations for the new genus Lecaimmeria were proposed, based on the four-loci phylogenetic trees. Keys to Immersaria, the new genus and allied genera are provided below.

\section{Materials And Methods}

\section{Morphological analysis}


All the materials for this study were collected in mainland China, mostly from the Qinghai-Tibetan Plateau, during the authors' participation in The Second Tibetan Plateau Scientific Expedition and Research Program. These specimens were stored in the Herbarium of the Kunming Institute of Botany, Chinese Academy of Sciences (KUN) and the Lichen Section of the Botanical Herbarium, Shandong Normal University (SDNU). Type specimens were loaned by the University of Helsinki $(\mathrm{H})$ and Universität Wien (WU). High-resolution photographs of type specimens were provided by the curators of $\mathrm{H}$ or obtained from the website Global Plants (https://plants.jstor.org/). Morphological descriptions were made under a dissecting microscope COIX. Anatomical descriptions were based on observations made of hand-cut sections, mounted in water and using a NIKON microscope. Photographs were captured with a NIKON Eclipse 50i microscope equipped with a NIKON digital camera (DSFi2 high-definition color camera head, NIKON, Japan). The specimens were tested with a $10 \%$ aqueous solution of potassium hydroxide (K), a solution of aqueous sodium hypochlorite (C) and 3\% Lugol's iodine (I) in the medulla and the surface of thallus. Secondary metabolites of all the specimens were examined by thin-layer chromatography (TLC) methods, using Solvents A, B and C, as described by Orange et al. (2001).

\section{Phylogenetic analysis}

Molecular analysis was carried out on the selected specimens. Genomic DNA was extracted from dry or fresh specimens using a DNAsecure Plant Kit (Tiangen), following the manufacturer's instructions. Five gene loci were amplified by using the following primers: ITS1F (Larena et al. 1999), ITS4 (White et al. 1990), LROR (Rehner and Samuels 1994), LR5 (Vilgalys and Hester 1990), gRPB1a (Stiller and Hall 1997), fRPB1c (Matheny et al. 2002), RPB2-6f, RPB2-7cr (Liu et al. 1999), mrSSU1 and mrSSU3R (Zoller et al. 1999). The $25 \mu \mathrm{l} \mathrm{PCR} \mathrm{mixture} \mathrm{consisted} \mathrm{of} 2 \mu \mathrm{l}$ DNA, $1 \mu$ l of each primer, $12.5 \mu \mathrm{l} 2 \times$ Taq PCR MasterMix (Aidlab) (Taq DNA Polymerase [0.1 unit/IL]; $4 \mathrm{mM} \mathrm{MgCl}_{2}$; and $0.4 \mathrm{mM}$ dNTPs) and $8.5 \mu \mathrm{ddH}_{2} \mathrm{O}$. Conditions for PCR of nrlTS, nrLSU and mtSSU were set for an initial denaturation at $94{ }^{\circ} \mathrm{C}$ for $10 \mathrm{~min}$, followed by 34 cycles of denaturation at $95^{\circ} \mathrm{C}$ for $45 \mathrm{~s}$, annealing at $50{ }^{\circ} \mathrm{C}$ for 45 $\mathrm{s}$, extension at $72^{\circ} \mathrm{C}$ for $90 \mathrm{~s}$, and a final extension at $72^{\circ} \mathrm{C}$ for $10 \mathrm{~min}$. For RPB1 and RPB2, the parameters were set to an initial denaturation at $94{ }^{\circ} \mathrm{C}$ for $10 \mathrm{~min}$, followed by 34 cycles of denaturation at $95^{\circ} \mathrm{C}$ for $45 \mathrm{~s}$, annealing at $52{ }^{\circ} \mathrm{C}$ for $50 \mathrm{~s}$, extension at $72{ }^{\circ} \mathrm{C}$ for $60 \mathrm{~s}$, and a final extension at $72^{\circ} \mathrm{C}$ for $5 \mathrm{~min}$. The PCR products were sequenced using Sanger technology by the company of Tsingke Biological Technology (Beijing).

The raw sequences were assembled and edited using SeqMan v.7.0 (DNAstar packages). Sequences extracted from new materials with each gene loci were aligned with additional sequences that were available from GenBank (Table 1), by using MEGA v.10.0 and an online version of MAFFT v.7.0 to generate nrITS-nrLSU-RPB1-RPB2-mtSSU or nrITS-nrLSU-RPB1-RPB2 matrices. The five or four gene matrices were combined by SequenceMatrix v.1.7.8. and the concatenated alignments were estimated by PartitionFinder 2 (Lanfear et al. 2017), based on Bayesian information criterion (BIC), to find the most appropriate nucleotide substitution model for each of the five loci. 
Table 1

Sequences included in this study. The new sequences generated are in bold.

\begin{tabular}{|c|c|c|c|c|c|c|c|}
\hline \multirow[t]{2}{*}{ Taxa } & \multirow[t]{2}{*}{ Locality } & \multirow{2}{*}{$\begin{array}{l}\text { Voucher } \\
\text { Specimens }\end{array}$} & \multicolumn{5}{|c|}{ GenBank accession number } \\
\hline & & & nrlTS & nrLSU & RPB1 & RPB2 & mtSSU \\
\hline $\begin{array}{l}\text { Amygdalaria } \\
\text { consentiens }\end{array}$ & Greenland & $\begin{array}{l}\text { J. Buschbom } \\
22.8 .2000-56\end{array}$ & - & AY532977 & - & - & - \\
\hline A. elegantior & Canada & $\begin{array}{l}\text { J. Buschbom } \\
16.7 .2000-38\end{array}$ & - & AY532979 & - & - & - \\
\hline A. panaeola & USA & J. Buschbom 3118 & - & AY532980 & - & - & - \\
\hline $\begin{array}{l}\text { Bellemerea } \\
\text { alpina }\end{array}$ & Unknown & Hafellner 46531 & AF332117 & - & - & - & - \\
\hline B. alpina & Greenland & $\begin{array}{l}\text { J. Buschbom } \\
23.8 .2000-22\end{array}$ & - & AY532982 & - & - & - \\
\hline $\begin{array}{l}B . \\
\text { cinereorufescens }\end{array}$ & USA & McCune 35490 & KY800500 & - & - & - & - \\
\hline B. subsorediza & Sweden & $\begin{array}{l}\text { J. Buschbom } \\
25.8 .2001-38 a\end{array}$ & - & AY532983 & - & - & - \\
\hline $\begin{array}{l}\text { Bryobilimbia } \\
\text { australis }\end{array}$ & Chile & $\begin{array}{l}\text { S. Pérez-Ortega } \\
1419\end{array}$ & KF683092 & - & KF683112 & - & - \\
\hline B. diapensiae & Sweden & Arup L04400 & HQ650660 & HQ660539 & - & - & HQ660564 \\
\hline B. hypnorum & Unknown & $\begin{array}{l}\text { F. Jonsson \& Z. } \\
\text { Palice } 10747\end{array}$ & KF683093 & - & - & - & - \\
\hline B. sanguineoatra & France & Sipman 44029 & HQ650664 & AY533005 & - & - & - \\
\hline $\begin{array}{l}\text { Clauzadea } \\
\text { monticola }\end{array}$ & USA & A. M. Fryday 9703 & KF683090 & KF692710 & - & - & - \\
\hline C. monticola & USA & A. M. Fryday 9728 & - & - & KF683113 & KF683110 & - \\
\hline $\begin{array}{l}\text { Cyclohymenia } \\
\text { epilithica }\end{array}$ & USA & McCune 31029 & KY800503 & KY800514 & - & - & - \\
\hline C. epilithica & USA & McCune 31068 & KY800504 & KY800513 & - & - & - \\
\hline Farnoldia jurana & Austria & $\begin{array}{l}\text { Herbarium Tuerk } \\
39660\end{array}$ & EU263920 & - & MK684889 & - & GU074511 \\
\hline F. jurana & Unknown & $\begin{array}{l}\text { J. Buschbom } \\
15.09 .2001-1\end{array}$ & - & AY532984 & - & - & - \\
\hline $\begin{array}{l}\text { Immersaria } \\
\text { athroocarpa }\end{array}$ & $\begin{array}{l}\text { China: } \\
\text { Inner } \\
\text { Mongolia }\end{array}$ & SDNU20190035 & MZ227390 & MZ227079 & - & MZ343462 & MZ227025 \\
\hline I. athroocarpa & $\begin{array}{l}\text { China: } \\
\text { Inner } \\
\text { Mongolia }\end{array}$ & SDNU20190140 & MZ227391 & MZ227080 & MZ343432 & MZ343461 & MZ227026 \\
\hline I. athroocarpa & $\begin{array}{l}\text { China: } \\
\text { Inner } \\
\text { Mongolia }\end{array}$ & SDNU20190143 & MZ227393 & MZ227081 & MZ343439 & - & - \\
\hline I. athroocarpa & $\begin{array}{l}\text { China: } \\
\text { Inner } \\
\text { Mongolia }\end{array}$ & SDNU20190227D & MZ227394 & - & MZ343433 & - & - \\
\hline I. athroocarpa & $\begin{array}{l}\text { China: } \\
\text { Inner } \\
\text { Mongolia }\end{array}$ & SDNU20190227 & MZ227395 & - & MZ343434 & - & - \\
\hline
\end{tabular}




\begin{tabular}{|c|c|c|c|c|c|c|c|}
\hline \multirow[t]{2}{*}{ Taxa } & \multirow[t]{2}{*}{ Locality } & \multirow{2}{*}{$\begin{array}{l}\text { Voucher } \\
\text { Specimens }\end{array}$} & \multicolumn{5}{|c|}{ GenBank accession number } \\
\hline & & & nrlTs & nrLSU & RPB1 & RPB2 & mtSSU \\
\hline I. aurantia & $\begin{array}{l}\text { China: } \\
\text { Qinghai }\end{array}$ & KUN 20-67809 & MZ227428 & MZ227101 & MZ343431 & - & MZ227031 \\
\hline I. aurantia & $\begin{array}{l}\text { China: } \\
\text { Sichuan }\end{array}$ & KUN 20-66701 & MZ227400 & MZ227092 & - & - & - \\
\hline I. aurantia & $\begin{array}{l}\text { China: } \\
\text { Sichuan }\end{array}$ & KUN 20-66708A & MZ227403 & MZ227093 & MZ343427 & - & - \\
\hline I. aurantia & $\begin{array}{l}\text { China: } \\
\text { Sichuan }\end{array}$ & KUN 20-66723 & MZ227408 & MZ227095 & - & - & - \\
\hline I. aurantia & $\begin{array}{l}\text { China: } \\
\text { Sichuan }\end{array}$ & KUN 20-66680 & MZ227483 & MZ227087 & - & - & - \\
\hline I. aurantia & $\begin{array}{l}\text { China: } \\
\text { Sichuan }\end{array}$ & KUN 20-66687 & MZ227485 & MZ227088 & - & - & - \\
\hline I. aurantia & $\begin{array}{l}\text { China: } \\
\text { Sichuan }\end{array}$ & KUN 20-66692 & MZ227486 & MZ227089 & - & - & - \\
\hline I. aurantia & $\begin{array}{l}\text { China: } \\
\text { Sichuan }\end{array}$ & KUN 20-66693 & MZ227487 & MZ227090 & - & - & - \\
\hline I. aurantia & $\begin{array}{l}\text { China: } \\
\text { Tibet }\end{array}$ & KUN 20-69114 & MZ227464 & MZ227116 & - & MZ343472 & - \\
\hline I. aurantia & $\begin{array}{l}\text { China: } \\
\text { Tibet }\end{array}$ & KUN 20-69122 & MZ227465 & MZ227117 & - & - & - \\
\hline I. aurantia & $\begin{array}{l}\text { China: } \\
\text { Tibet }\end{array}$ & KUN 20-69091 & MZ227461 & - & - & MZ343465 & - \\
\hline I. aurantia & $\begin{array}{l}\text { China: } \\
\text { Tibet }\end{array}$ & KUN 20-69094 & MZ227462 & MZ227114 & - & - & - \\
\hline I. aurantia & $\begin{array}{l}\text { China: } \\
\text { Tibet }\end{array}$ & KUN XY19-1290 & MZ227473 & MZ227084 & - & - & - \\
\hline I. ferruginea & $\begin{array}{l}\text { China: } \\
\text { Sichuan }\end{array}$ & KUN 20-66697A & MZ227399 & MZ227091 & - & - & - \\
\hline I. ferruginea & $\begin{array}{l}\text { China: } \\
\text { Sichuan }\end{array}$ & KUN 20-67670 & MZ227426 & MZ227100 & MZ343441 & - & - \\
\hline I. ferruginea & $\begin{array}{l}\text { China: } \\
\text { Tibet }\end{array}$ & KUN 20-69105 & MZ227463 & MZ227115 & - & MZ343469 & - \\
\hline I. ferruginea & $\begin{array}{l}\text { China: } \\
\text { Tibet }\end{array}$ & KUN 20-69144 & MZ227466 & MZ227118 & MZ343417 & MZ343470 & MZ227034 \\
\hline I. ferruginea & $\begin{array}{l}\text { China: } \\
\text { Tibet }\end{array}$ & KUN 20-69146 & MZ227467 & MZ227119 & - & MZ343471 & - \\
\hline I. ferruginea & $\begin{array}{l}\text { China: } \\
\text { Tibet }\end{array}$ & KUN 20-69148 & MZ227468 & MZ227120 & - & MZ343468 & - \\
\hline $\begin{array}{l}\text { I. } \\
\text { plumbeoolivacea }\end{array}$ & $\begin{array}{l}\text { China: } \\
\text { Qinghai }\end{array}$ & KUN 20-66889 & MZ227430 & MZ227102 & MZ343435 & MZ343467 & - \\
\hline $\begin{array}{l}\text { I. } \\
\text { plumbeoolivacea }\end{array}$ & $\begin{array}{l}\text { China: } \\
\text { Qinghai }\end{array}$ & KUN 20-66914 & MZ227437 & MZ227103 & MZ343405 & MZ343464 & MZ227032 \\
\hline $\begin{array}{l}\text { I. } \\
\text { plumbeoolivacea }\end{array}$ & $\begin{array}{l}\text { China: } \\
\text { Qinghai }\end{array}$ & KUN 20-66915 & MZ227438 & MZ227104 & MZ343436 & MZ343463 & MZ227033 \\
\hline $\begin{array}{l}\text { I. } \\
\text { plumbeoolivacea }\end{array}$ & $\begin{array}{l}\text { China: } \\
\text { Qinghai }\end{array}$ & KUN 20-67896 & MZ227446 & MZ227108 & MZ343413 & - & - \\
\hline
\end{tabular}




\begin{tabular}{|c|c|c|c|c|c|c|c|}
\hline \multirow[t]{2}{*}{ Taxa } & \multirow[t]{2}{*}{ Locality } & \multirow{2}{*}{$\begin{array}{l}\text { Voucher } \\
\text { Specimens }\end{array}$} & \multicolumn{5}{|c|}{ GenBank accession number } \\
\hline & & & nrlTs & nrLSU & RPB1 & RPB2 & mtSSU \\
\hline I. shangrilaensis & $\begin{array}{l}\text { China: } \\
\text { Yunnan }\end{array}$ & SDNU20181696 & MZ227392 & - & - & - & - \\
\hline I. shangrilaensis & $\begin{array}{l}\text { China: } \\
\text { Yunnan }\end{array}$ & KUN 18-60447 & MZ227472 & MZ227083 & - & - & - \\
\hline I. venusta & $\begin{array}{l}\text { China: } \\
\text { Qinghai }\end{array}$ & KUN 20-66933 & MZ227439 & MZ227105 & MZ343438 & - & - \\
\hline I. venusta & $\begin{array}{l}\text { China: } \\
\text { Qinghai }\end{array}$ & KUN 20-66940 & MZ227441 & MZ227106 & MZ343406 & - & - \\
\hline I. venusta & $\begin{array}{l}\text { China: } \\
\text { Qinghai }\end{array}$ & KUN 20-68157 & MZ227452 & MZ227112 & MZ343424 & MZ343458 & - \\
\hline I. venusta & $\begin{array}{l}\text { China: } \\
\text { Qinghai }\end{array}$ & KUN 20-66796 & MZ227413 & MZ227097 & MZ343430 & - & - \\
\hline I. venusta & $\begin{array}{l}\text { China: } \\
\text { Qinghai }\end{array}$ & KUN 20-66808 & MZ227416 & MZ227098 & MZ343426 & - & MZ227028 \\
\hline I. venusta & $\begin{array}{l}\text { China: } \\
\text { Qinghai }\end{array}$ & KUN 20-66810 & MZ227417 & MZ227099 & MZ343428 & MZ343473 & MZ227029 \\
\hline I. venusta & $\begin{array}{l}\text { China: } \\
\text { Qinghai }\end{array}$ & KUN 20-66824 & MZ227421 & - & MZ343423 & MZ343460 & - \\
\hline I. venusta & $\begin{array}{l}\text { China: } \\
\text { Qinghai }\end{array}$ & KUN 20-66977 & MZ227444 & MZ227107 & - & MZ343466 & - \\
\hline I. venusta & $\begin{array}{l}\text { China: } \\
\text { Qinghai }\end{array}$ & KUN 20-2811 & MZ227480 & MZ227085 & MZ343440 & - & - \\
\hline I. venusta & $\begin{array}{l}\text { China: } \\
\text { Qinghai }\end{array}$ & KUN 20-2799 & MZ227481 & - & MZ343398 & - & - \\
\hline I. venusta & $\begin{array}{l}\text { China: } \\
\text { Qinghai }\end{array}$ & KUN 20-67959 & MZ227447 & MZ227109 & MZ343437 & - & - \\
\hline I. venusta & $\begin{array}{l}\text { China: } \\
\text { Qinghai }\end{array}$ & KUN 20-67965 & MZ227448 & MZ227110 & MZ343429 & - & - \\
\hline I. venusta & $\begin{array}{l}\text { China: } \\
\text { Qinghai }\end{array}$ & KUN 20-67969A & MZ227449 & MZ227111 & MZ343425 & - & - \\
\hline I. venusta & $\begin{array}{l}\text { China: } \\
\text { Sichuan }\end{array}$ & KUN 20-66607 & MZ227482 & MZ227086 & - & - & - \\
\hline I. venusta & $\begin{array}{l}\text { China: } \\
\text { Sichuan }\end{array}$ & KUN 20-66721C & MZ227407 & MZ227094 & - & - & - \\
\hline I. venusta & $\begin{array}{l}\text { China: } \\
\text { Sichuan }\end{array}$ & KUN 20-66725 & MZ227409 & MZ227096 & - & - & - \\
\hline I. venusta & $\begin{array}{l}\text { China: } \\
\text { Sichuan }\end{array}$ & KUN 20-68802 & MZ227456 & MZ227113 & MZ343399 & MZ343459 & - \\
\hline Immersaria sp. & Macedonia & Malicek 7717 & MF149862 & - & - & - & MF149861 \\
\hline $\begin{array}{l}\text { Koerberiella } \\
\text { wimmeriana }\end{array}$ & Norway & O-L-163472 & MK812168 & - & - & - & - \\
\hline $\begin{array}{l}\text { Lecaimmeria } \\
\text { botryoides }\end{array}$ & $\begin{array}{l}\text { China: } \\
\text { Sichuan }\end{array}$ & KUN 20-66706 & MZ227401 & MZ227046 & - & - & - \\
\hline L. botryoides & $\begin{array}{l}\text { China: } \\
\text { Qinghai }\end{array}$ & KUN 20-66765 & MZ227412 & MZ227053 & MZ343400 & MZ343457 & $M Z 227027$ \\
\hline
\end{tabular}




\begin{tabular}{|c|c|c|c|c|c|c|c|}
\hline \multirow[t]{2}{*}{ Taxa } & \multirow[t]{2}{*}{ Locality } & \multirow{2}{*}{$\begin{array}{l}\text { Voucher } \\
\text { Specimens }\end{array}$} & \multicolumn{5}{|c|}{ GenBank accession number } \\
\hline & & & nrlTS & nrLSU & RPB1 & RPB2 & mtSSU \\
\hline L. botryoides & $\begin{array}{l}\text { China: } \\
\text { Qinghai }\end{array}$ & KUN 20-66891 & MZ227431 & - & MZ343422 & - & - \\
\hline L. botryoides & $\begin{array}{l}\text { China: } \\
\text { Qinghai }\end{array}$ & KUN 20-66898 & - & - & MZ343408 & - & - \\
\hline L. botryoides & $\begin{array}{l}\text { China: } \\
\text { Qinghai }\end{array}$ & KUN 20-66900 & MZ227434 & - & - & - & - \\
\hline L. botryoides & $\begin{array}{l}\text { China: } \\
\text { Sichuan }\end{array}$ & KUN 20-66707 & MZ227402 & MZ227047 & - & - & - \\
\hline L. botryoides & $\begin{array}{l}\text { China: } \\
\text { Sichuan }\end{array}$ & KUN 20-66711 & MZ227404 & MZ227048 & - & - & - \\
\hline L. botryoides & $\begin{array}{l}\text { China: } \\
\text { Sichuan }\end{array}$ & KUN 20-66713 & MZ227405 & MZ227049 & MZ343403 & - & - \\
\hline L. botryoides & $\begin{array}{l}\text { China: } \\
\text { Sichuan }\end{array}$ & KUN 20-66721A & MZ227406 & MZ227050 & - & MZ343456 & - \\
\hline L. botryoides & $\begin{array}{l}\text { China: } \\
\text { Sichuan }\end{array}$ & KUN 20-66730 & MZ227410 & MZ227051 & - & - & - \\
\hline L. botryoides & $\begin{array}{l}\text { China: } \\
\text { Sichuan }\end{array}$ & KUN 20-67706 & MZ227427 & MZ227063 & - & - & - \\
\hline L. botryoides & $\begin{array}{l}\text { China: } \\
\text { Sichuan }\end{array}$ & KUN 20-66683 & MZ227484 & MZ227045 & - & - & - \\
\hline L. lygaea & $\begin{array}{l}\text { China: } \\
\text { Tibet }\end{array}$ & KUN 20-69053 & MZ227457 & - & - & - & - \\
\hline L. iranic & China & SDNU20117663 & KR061347 & - & - & - & - \\
\hline L. iranic & China & SDNU20117623 & KR061348 & - & - & - & - \\
\hline L. lygaea & $\begin{array}{l}\text { China: } \\
\text { Tibet }\end{array}$ & KUN 20-69054 & $M Z 227458$ & MZ227075 & - & - & - \\
\hline L. lygaea & $\begin{array}{l}\text { China: } \\
\text { Tibet }\end{array}$ & KUN 20-69070 & MZ227459 & MZ227076 & - & - & - \\
\hline L. lygaea & $\begin{array}{l}\text { China: } \\
\text { Tibet }\end{array}$ & KUN 20-69072 & MZ227460 & MZ227077 & - & MZ343449 & - \\
\hline L. mongolica & $\begin{array}{l}\text { China: } \\
\text { Inner } \\
\text { Mongolia }\end{array}$ & SDNU20190354 & MZ227389 & MZ227038 & MZ343404 & - & - \\
\hline L. mongolica & $\begin{array}{l}\text { China: } \\
\text { Inner } \\
\text { Mongolia }\end{array}$ & SDNU20190350 & MZ227388 & MZ227037 & - & - & - \\
\hline L. mongolica & $\begin{array}{l}\text { China: } \\
\text { Inner } \\
\text { Mongolia }\end{array}$ & SDNU20117851 & MZ227396 & - & - & - & - \\
\hline L. mongolica & $\begin{array}{l}\text { China: } \\
\text { Inner } \\
\text { Mongolia }\end{array}$ & SDNU20117613 & MZ227397 & - & - & - & - \\
\hline L. mongolica & $\begin{array}{l}\text { China: } \\
\text { Inner } \\
\text { Mongolia }\end{array}$ & SDNU20117399 & MZ227398 & - & - & - & - \\
\hline L. orbicularis & $\begin{array}{l}\text { China: } \\
\text { Qinghai }\end{array}$ & KUN 20-66886B & MZ227429 & MZ227064 & MZ343416 & - & - \\
\hline
\end{tabular}




\begin{tabular}{|c|c|c|c|c|c|c|c|}
\hline \multirow[t]{2}{*}{ Taxa } & \multirow[t]{2}{*}{ Locality } & \multirow{2}{*}{$\begin{array}{l}\text { Voucher } \\
\text { Specimens }\end{array}$} & \multicolumn{5}{|c|}{ GenBank accession number } \\
\hline & & & nrlTs & nrLSU & RPB1 & RPB2 & mtSSU \\
\hline L. orbicularis & $\begin{array}{l}\text { China: } \\
\text { Qinghai }\end{array}$ & KUN 20-66896 & MZ227432 & MZ227065 & MZ343402 & - & - \\
\hline L. orbicularis & $\begin{array}{l}\text { China: } \\
\text { Qinghai }\end{array}$ & KUN 20-66899 & MZ227433 & MZ227066 & MZ343401 & - & - \\
\hline L. orbicularis & $\begin{array}{l}\text { China: } \\
\text { Qinghai }\end{array}$ & KUN 20-66901 & MZ227435 & - & - & - & - \\
\hline L. orbicularis & $\begin{array}{l}\text { China: } \\
\text { Qinghai }\end{array}$ & KUN 20-66908 & - & MZ227070 & MZ343415 & MZ343442 & - \\
\hline L. orbicularis & $\begin{array}{l}\text { China: } \\
\text { Qinghai }\end{array}$ & KUN 20-66909 & - & - & MZ343394 & MZ343446 & - \\
\hline L. orbicularis & $\begin{array}{l}\text { China: } \\
\text { Qinghai }\end{array}$ & KUN 20-66935 & MZ227440 & MZ227071 & MZ343421 & - & - \\
\hline L. orbicularis & $\begin{array}{l}\text { China: } \\
\text { Qinghai }\end{array}$ & KUN 20-66943 & MZ227442 & MZ227072 & MZ343418 & MZ343445 & - \\
\hline L. orbicularis & $\begin{array}{l}\text { China: } \\
\text { Qinghai }\end{array}$ & KUN 20-66801 & MZ227414 & MZ227054 & - & - & - \\
\hline L. orbicularis & $\begin{array}{l}\text { China: } \\
\text { Qinghai }\end{array}$ & KUN 20-66803 & MZ227415 & MZ227055 & - & - & - \\
\hline L. orbicularis & $\begin{array}{l}\text { China: } \\
\text { Qinghai }\end{array}$ & KUN 20-66811 & MZ227418 & MZ227056 & - & - & - \\
\hline L. orbicularis & $\begin{array}{l}\text { China: } \\
\text { Qinghai }\end{array}$ & KUN 20-66817 & MZ227419 & MZ227057 & MZ343409 & - & - \\
\hline L. orbicularis & $\begin{array}{l}\text { China: } \\
\text { Qinghai }\end{array}$ & KUN 20-66821 & MZ227420 & MZ227058 & - & - & - \\
\hline L. orbicularis & $\begin{array}{l}\text { China: } \\
\text { Qinghai }\end{array}$ & KUN 20-66826A & MZ227422 & MZ227059 & MZ343396 & - & - \\
\hline L. orbicularis & $\begin{array}{l}\text { China: } \\
\text { Qinghai }\end{array}$ & KUN 20-66829 & MZ227423 & MZ227060 & MZ343395 & - & - \\
\hline L. orbicularis & $\begin{array}{l}\text { China: } \\
\text { Qinghai }\end{array}$ & KUN 20-66833 & MZ227424 & MZ227061 & MZ343410 & MZ343443 & MZ227030 \\
\hline L. orbicularis & $\begin{array}{l}\text { China: } \\
\text { Qinghai }\end{array}$ & KUN 20-66841 & MZ227425 & MZ227062 & MZ343414 & - & - \\
\hline L. orbicularis & $\begin{array}{l}\text { China: } \\
\text { Qinghai }\end{array}$ & KUN 20-66965 & MZ227443 & MZ227073 & MZ343411 & - & - \\
\hline L. orbicularis & $\begin{array}{l}\text { China: } \\
\text { Qinghai }\end{array}$ & KUN 20-66979 & MZ227445 & MZ227074 & MZ343407 & MZ343448 & - \\
\hline L. orbicularis & $\begin{array}{l}\text { China: } \\
\text { Sichuan }\end{array}$ & KUN 20-66747 & MZ227436 & MZ227067 & MZ343397 & MZ343447 & - \\
\hline L. orbicularis & $\begin{array}{l}\text { China: } \\
\text { Sichuan }\end{array}$ & KUN 20-66750 & - & MZ227068 & - & - & - \\
\hline L. orbicularis & $\begin{array}{l}\text { China: } \\
\text { Sichuan }\end{array}$ & KUN 20-66753 & - & MZ227069 & MZ343412 & MZ343444 & - \\
\hline L. orbicularis & $\begin{array}{l}\text { China: } \\
\text { Sichuan }\end{array}$ & KUN 20-66743 & MZ227411 & MZ227052 & - & - & - \\
\hline L. qinghaiensis & $\begin{array}{l}\text { China: } \\
\text { Qinghai }\end{array}$ & KUN 20-3127 & MZ227471 & - & - & MZ343454 & - \\
\hline
\end{tabular}




\begin{tabular}{|c|c|c|c|c|c|c|c|}
\hline \multirow[t]{2}{*}{ Taxa } & \multirow[t]{2}{*}{ Locality } & \multirow{2}{*}{$\begin{array}{l}\text { Voucher } \\
\text { Specimens }\end{array}$} & \multicolumn{5}{|c|}{ GenBank accession number } \\
\hline & & & nrlTS & nrLSU & RPB1 & RPB2 & mtSSU \\
\hline L. qinghaiensis & $\begin{array}{l}\text { China: } \\
\text { Qinghai }\end{array}$ & KUN 20-68687 & MZ227453 & - & - & - & - \\
\hline L. qinghaiensis & $\begin{array}{l}\text { China: } \\
\text { Qinghai }\end{array}$ & KUN 20-68696 & MZ227454 & - & - & - & - \\
\hline L. qinghaiensis & $\begin{array}{l}\text { China: } \\
\text { Qinghai }\end{array}$ & KUN 20-68698 & MZ227455 & - & MZ343420 & MZ343450 & - \\
\hline L. qinghaiensis & $\begin{array}{l}\text { China: } \\
\text { Qinghai }\end{array}$ & KUN 20-3115 & MZ227470 & - & - & MZ343453 & - \\
\hline L. qinghaiensis & $\begin{array}{l}\text { China: } \\
\text { Qinghai }\end{array}$ & KUN 20-849 & MZ227469 & MZ227078 & MZ343419 & MZ343452 & MZ227035 \\
\hline L. tibetica & $\begin{array}{l}\text { China: } \\
\text { Tibet }\end{array}$ & KUN 19-64071 & - & MZ227082 & - & - & - \\
\hline L. tibetica & $\begin{array}{l}\text { China: } \\
\text { Tibet }\end{array}$ & KUN XY19-1288i & MZ227474 & MZ227039 & - & - & MZ227036 \\
\hline L. tibetica & $\begin{array}{l}\text { China: } \\
\text { Tibet }\end{array}$ & KUN XY19-1288A & MZ227475 & MZ227040 & - & - & - \\
\hline L. tuberculosa & $\begin{array}{l}\text { China: } \\
\text { Gansu }\end{array}$ & KUN 18-58856 & MZ227476 & MZ227041 & - & - & - \\
\hline L. tuberculosa & $\begin{array}{l}\text { China: } \\
\text { Gansu }\end{array}$ & KUN 18-58857 & MZ227477 & MZ227042 & - & - & - \\
\hline L. tuberculosa & $\begin{array}{l}\text { China: } \\
\text { Gansu }\end{array}$ & KUN 18-58865A & MZ227478 & MZ227043 & - & - & - \\
\hline L. tuberculosa & $\begin{array}{l}\text { China: } \\
\text { Gansu }\end{array}$ & KUN 18-59835 & MZ227479 & MZ227044 & - & - & - \\
\hline L. tuberculosa & $\begin{array}{l}\text { China: } \\
\text { Qinghai }\end{array}$ & KUN 20-68077 & MZ227450 & - & - & MZ343451 & - \\
\hline L. tuberculosa & $\begin{array}{l}\text { China: } \\
\text { Qinghai }\end{array}$ & KUN 20-68055 & MZ227451 & - & - & MZ343455 & - \\
\hline $\begin{array}{l}\text { Lecidea } \\
\text { atrobrunnea }\end{array}$ & Antarctica & AAS_Convey00458 & MK620076 & - & MK684891 & HQ660524 & MK684569 \\
\hline L. auriculata & Argentina & UR00061 & MK620123 & - & MK684941 & - & MK684627 \\
\hline L. berengeriana & Unknown & Arup L00015 & HQ650659 & HQ660537 & - & HQ660526 & HQ660562 \\
\hline L. confluens & Unknown & $\begin{array}{l}\text { J. Buschbom } \\
21.8 .2001-44\end{array}$ & - & AY532994 & - & - & - \\
\hline L. confluens & Austria & $\begin{array}{l}\text { Herbarium Tuerk } \\
39641\end{array}$ & - & - & - & - & GU074492 \\
\hline L. fuscoatra & Sweden & Arup L02894 & HQ650662 & HQ660541 & - & HQ660528 & HQ660566 \\
\hline L. grisella & Turkey & Trabzon 2 & HQ605931 & - & - & - & - \\
\hline L. grisella & Sweden & Arup L02723 & - & HQ660542 & - & HQ660529 & HQ660567 \\
\hline L. laboriosa & USA & $\begin{array}{l}\text { F. Lutzoni et al. } \\
03.09 .05-5\end{array}$ & - & KJ766586 & - & DQ992432 & - \\
\hline L. laboriosa & Unknown & $\begin{array}{l}\text { U.C. Riverside } \\
\text { 43266UCR1 }\end{array}$ & - & - & MK684890 & - & GU074503 \\
\hline L. lapicida & USA & Lendemer 11081 & HQ650665 & HQ660544 & - & HQ660530 & HQ660570 \\
\hline
\end{tabular}




\begin{tabular}{|c|c|c|c|c|c|c|c|}
\hline \multirow[t]{2}{*}{ Taxa } & \multirow[t]{2}{*}{ Locality } & \multirow{2}{*}{$\begin{array}{l}\text { Voucher } \\
\text { Specimens }\end{array}$} & \multicolumn{5}{|c|}{ GenBank accession number } \\
\hline & & & nrlTs & nrLSU & RPB1 & RPB2 & mtSSU \\
\hline L. lithophila & Canada & UR00246 & MK620247 & - & MK685037 & - & MK684743 \\
\hline L. plana & Sweden & LD L03170 & EU259903 & - & - & KF683111 & GU074497 \\
\hline L. promiscens & Argentina & UR00129 & KX120205 & - & MK684964 & - & MK684661 \\
\hline L. silacea & Unknown & AFTOL-ID 1368 & HQ650629 & - & DQ986820 & DQ992431 & - \\
\hline L. silacea & Unknown & Wedin 6865 & - & AY756340 & - & - & - \\
\hline L. silacea & Unknown & $\begin{array}{l}\text { Herbarium Tuerk } \\
42156\end{array}$ & - & - & - & - & GU074496 \\
\hline L. tessellata & Unknown & Lay 01-0360 & HQ650671 & HQ660548 & - & - & - \\
\hline L. uniformis & USA & Hollinger 6775 & NR_158514 & KY800515 & - & - & - \\
\hline $\begin{array}{l}\text { Lecidoma } \\
\text { demissum }\end{array}$ & Unknown & AFTOL 1376 & HQ650630 & - & KJ766867 & DQ992445 & - \\
\hline $\begin{array}{l}\text { Pachyphysis } \\
\text { ozarkana }\end{array}$ & Unknown & $\begin{array}{l}\text { J. Buschbom } \\
11.10 .1997-2\end{array}$ & - & AY532988 & - & - & - \\
\hline $\begin{array}{l}\text { Poeltidea cf. } \\
\text { perusta }\end{array}$ & Chile & UR00026 & MK620106 & - & MK684886 & - & MK684599 \\
\hline P. perusta & Chile & UR00039 & MK620112 & - & MK684888 & - & MK684609 \\
\hline $\begin{array}{l}\text { Porpidia } \\
\text { albocaerulescens }\end{array}$ & USA & Tripp 2279 & KJ653475 & - & - & DQ992443 & - \\
\hline P. cinereoatra & $\begin{array}{l}\text { United } \\
\text { Kingdom }\end{array}$ & Orange 20432 & KJ162305 & - & - & - & - \\
\hline P. cinereoatra & Unknown & $\begin{array}{l}\text { J. Buschbom } \\
30.8 .2001-1\end{array}$ & - & AY532941 & - & - & - \\
\hline P. cinereoatra & Unknown & J. Guccion 1187 & - & - & - & - & KF683104 \\
\hline P. contraponenda & $\begin{array}{l}\text { United } \\
\text { Kingdom }\end{array}$ & Orange 20447 & KJ162297 & - & - & - & - \\
\hline P. contraponenda & Unknown & K. Glew 000810-2 & - & AY532942 & - & - & - \\
\hline P. degelii & USA & Tripp 2503 & KJ653479 & - & - & - & KJ653473 \\
\hline P. grisea & China & SDNU YN0116 & KY509524 & - & - & - & - \\
\hline P. grisea & Unknown & $\begin{array}{l}\text { J. Buschbom } \\
25.8 .1999-15\end{array}$ & - & AY532951 & - & - & - \\
\hline P. hydrophila & $\begin{array}{l}\text { United } \\
\text { Kingdom }\end{array}$ & Orange 16218 & KJ162317 & - & - & - & - \\
\hline P. hyposticta & China & SDNU:20141385 & NR_156592 & - & - & - & - \\
\hline P. macrocarpa & Austria & $\begin{array}{l}\text { Herbarium Tuerk } \\
39740\end{array}$ & EU263923 & - & - & - & GU074512 \\
\hline P. macrocarpa & Austria & UR00411 & MK620258 & - & MK685056 & - & MK684730 \\
\hline P. speirea & China & SDNU20140742 & KY509523 & - & - & - & - \\
\hline P. speirea & Unknown & AFTOL 1050 & - & DQ986758 & DQ986829 & DQ992444 & - \\
\hline $\begin{array}{l}\text { Rhizocarpon } \\
\text { disporum }\end{array}$ & Unknown & $\begin{array}{l}\text { Lutzoni } 96.10 .26-9 \\
\text { st.1 }(1 / 2)\end{array}$ & - & AF356678 & - & AY641069 & - \\
\hline
\end{tabular}




\begin{tabular}{|llllllll|}
\hline Taxa & Locality & $\begin{array}{l}\text { Voucher } \\
\text { Specimens }\end{array}$ & \multicolumn{2}{l}{ GenBank accession number } & & \\
\cline { 3 - 7 } & & & nrlTS & nrLSU & RPB1 & RPB2 & mtSSU \\
\hline R. geographicum & Norway & Ihlen 941 & AF483619 & AY853389 & - & - & AF483187 \\
\hline Romjularia lurida & Spain & $\begin{array}{l}\text { S. Pérez-Ortega } \\
\text { 1372 }\end{array}$ & KF683091 & KF683107 & EF524328 & - & - \\
\hline
\end{tabular}

Phylogenetic relationships were inferred using Bayesian inference (BI) and Maximum likelihood (ML). $\mathrm{ML}$ analyses were performed with RaxMLHPC using general time reversible model of nucleotide substitution with the gamma model of rate heterogeneity (GTRGAMMA or GTRCAT). The analyses were run with a rapid bootstrap analysis using 1000 replicates with data partitioned. Bayesian method was performed with MrBayes v3.1.2 (Huelsenbeck and Ronquist 2001). Four Markov chains were run with 2 million generations for each data set and trees were sampled every 100 generations. It was ensured that the average standard deviation of split frequencies was lower than 0.01 . Posterior probabilities above 0.7 and bootstrap support above $40 \%$ were considered significant supporting values. All the trees were visualized with FigTree v 1.4.0 (Rambaut 2012).

\section{Results}

A total of 188 sequences of the nrITS, nrLSU, RPB1, RPB2 and mtSSU were generated from 75 specimens representing 65 species. Although the five-loci tree only poorly resolved the hierarchy of genera within the family Lecideaceae, nonetheless the results revealed that the genus Immersaria was not a monophyletic lineage. Rather, it was divided into two distant and well-supported lineages: Clade 1 which contained the lecideine apothecia species and Clade 2 which contained the lecanorine apothecia species (Fig. 1).

Clade 1 formed a highly supported clade (94\% MLBS and 1.00 PP) with Amygdalaria Norman, Cyclohymenia McCune \& M.J. Curtis, Lecidea s str. and Porpidia Körb. (Fig. 1), all of which have lecideine apothecia. Amygdalaria, Porpidia and Lecidea s str. were nested together, which is consistent with the results of previous research (Buschbom and Mueller 2004, Fryday et al. 2014). However, the relationships between these genera still need further research. There was a high level of support for a monophyletic lineage of lecideine apothecia species of Immersaria, with these being sister to the Lecidea tessellata, L. auriculata, Cyclohymenia and Porpidia albocaerulescens group. As the type species of its genus, Immersaria athroocarpa was included in the lineage. Thus, only those Immersaria species with lecideine apothecia were recognized as belonging to the genus Immersaria. This revised concept of the genus Immersaria is as follows: wax glossy thallus with an epinecral layer, immersed lecideine apothecia with a reduced margin, and Porpidia-type asci with halonate ascospores.

There was also a high level of support for Clade 2 as a monophyletic lineage (99\% MLBS and 1.00 PP) which was clustered within the same family as the other lecanorine apothecia genera: Bellemerea and Koerberiella (Fig. 1). Bellemerea was the sister group of Koerberiella and Clade 2, but was distinguished by its white thallus and amyloid ascospores. Koerberiella was sister to Clade 2, but differed in the presence of spherical isidia and adnate apothecia. Although there is only a low supporting value for the node of Koerberiella and Clade 2, there are conspicuous differences in their morphology and sufficient differences between the bases in their nucleotide sequences. Therefore, a new genus, Lecaimmeria, was proposed to accommodate Clade 2, which has immersed lecanorine apothecia with a white margin, and orange epihymenium with an epinecral layer.

Two additional phylogenetic trees were constructed, based on four loci (nrITS, nrLSU, RPB1 and RPB2), in order to assess the phylogenetic position of species within Immersaria and Lecaimmeria respectively. The phylogenetic tree of Immersaria was comprised of one highly supported clade with six separate lineages, based on 137 sequences from 51 specimens (Fig. 2). All the species with brown, orange, rusty, irregular or aggregate thalli formed respective monophyletic lineages. I. ferruginea C.M. Xie \& Li S. Wang formed a sister group to I. plumbeoolivacea C.M. Xie \& Xin Y. Wang, but differed in its rusty thallus and green epihymenium. I. shangrilaensis C.M. Xie \& Lu L. Zhang formed a well-supported clade sister to I. athroocarpa, I. auranitum C.M. Xie \& Li S. Wang and I. venusta C.M. Xie \& Xin Y. Wang, but the aggregate areolae clearly distinguished I. shangrilaensis from these other species. The robust lineage $I$. auranitum formed a weakly supported clade sister to $I$. athroocarpa and $I$. venusta, but could be distinguished by its irregular, conspicuously orange thallus and green epihymenium. I. athroocarpa was sister to I. venusta, but differed in its convex, polygon areolae and densely crowded apothecia. 
The phylogenetic tree of Lecaimmeria was comprised of one well-supported clade with nine separate lineages, based on 195 sequences from 66 specimens (Fig. 3). "Immersaria" sp. and Lecaimmeria iranica (Valadb., Sipman \& Rambold) C.M. Xie were the basal group. "Immersaria" sp. has only been recorded from Macedonia and L. iranica has been recorded from Inner Mongolia in China or from Iran. L. tuberculosa C.M. Xie \& Xin Y. Wang was sister to L. qinghaiensis C.M. Xie \& Li S. Wang, but conspicuously differed in its tuberculiform pycnidia. L. mongolica C.M. Xie \& Lu L. Zhang formed a well-supported monophyletic lineage, and its population was mainly recognized by its orange, irregular areolae and gyrophoric acid content. L. botryoides C.M. Xie \& Li S. Wang formed a highly supported sister group to L. orbicularis C.M. Xie \& Lu L. Zhang, L. lygaea C.M. Xie \& Lu L. Zhang and L. tibetica C.M. Xie \& Xin Y. Wang, but differed in its crowded apothecia. L. orbicularis formed a highly supported sister group to L. Iygaea and L. tibetica, but differed in its round apothecia and white margin of apothecia. L. lygaea was sister to $L$. tibetica, and differed in its black margin of areolae and well-developed prothallus between areolae.

\section{Discussion}

Revised boundaries of Immersaria

Formerly, the boundaries for Immersaria species were: the types of apothecia, the substances detected and the shapes of pycnidia. However, these characters were not stable characters by which to distinguish this genus. There were repeated reassignments of the lecanorine species Immersaria cupreoatra between Bellemerea and Immersaria. Based on many specimens from China, it was also discovered that the ostiole or stellate shapes of pycnidia appeared in different stages of ontogeny. The main substances of the genus are confluentic acid and gyrophoric acid; confluentic acid only occurs in lecideine species whereas gyrophoric acid appears in lecanorine species, with the exception of one lecideine species I. usberkica. Furthermore, these characters, the types of apothecia and the shapes of pycnidia, could not be applied as proper delimitations to classify species within Immersaria, neither were they supported by phylogeny.

The five-loci based analysis was incompatible with previous circumscriptions of the genus Immersaria, the members of which are currently defined by their lecideine immersed apothecia, brown areolae with an epinecral layer and brown/green epihymenium without an epinecral layer, with additional phylogenetic support. A new genus Lecaimmeria was established to accommodate the excluded lecanorine species. The new taxonomic system revised the classification boundaries between Immersaria and Lecaimmeria, but it may still be difficult to distinguish them in cases when apothecia are absent. In this case, they could be distinguished by their substances or by establishing the phylogenetic tree.

Diagnostic traits within species of Immersaria and Lecaimmeria

Species of Immersaria could be identified by their different thallus colors (marked in Fig. 2). Immersaria ferruginea and $I$. plumbeoolivacea both have a conspicuously grayish brown thallus, whereas I. athroocarpa, I. aurantia, I. shangrilaensis and I. venusta have a reddish brown thallus. I. athroocarpa and I. plumbeoolivacea (marked in Fig. 2) are species that mostly have green epihymenium whereas the other species mostly have brown epihymenium. Almost all these species contain confluentic acid, which is often accompanied by 2'-0-methylmicrophylinic acid. Planaic acid, which was firstly reported from this the genus, was only apparent in species of $I$. aurantia, I. shangrilaensis and $I$. venusta. All the characters discussed above were supported by phylogeny.

Species of the new genus Lecaimmeria could be delimited by the colors of its areolae and its margin, the existence of apothecia's margin and usually by the lack of substances. The margin of areolae (marked in Fig. 3) was usually white, but rarely black or jade green. Lecaimmeria lygaea could be easily distinguished by the black margin of areolae. The jade green margin occurs in $L$. tuberculosa, which grows on Qilian jade. The areolae margin of L. qinghaiensis is white, but is occasionally pigmented with very slightly green color. The margin of apothecia is absent in species $L$. tuberculosa and L. iranica whereas the apothecia of the other species have white margins. The substances in species of Lecaimmeria are usually absent. Gyrophoric acid was only detected in $L$. botryoides, L. iranica and L. mongolica (marked in Fig. 3). In addition, an orange thallus appeared only in L. mongolica and $L$. tibetica, whereas the remaining species were brownish.

\section{Taxonomy}

Immersaria Rambold \& Pietschm., Bibliotheca Lichenologica 34: 239 (1989)

Page $12 / 39$ 
Type: Immersaria athroocarpa (Ach.) Rambold \& Pietschm., in Rambold, Biblthca Lichenol. 34: 240 (1989).

\section{Description}

Thallus crustose, yellow brown, red brown, orange brown or brown, sometimes with rusty colored, continuous, areolae irregular or tend to rectangular, with wax glossy, margin pruinose, areolae sometimes aggregate with black prothallus and forming bigger areolae, prothallus distinct at the margin of thallus or absent. Upper cortex with orange pigmented, epinecral layer colorless, algal layer continuous, medulla filled with gray granules, lower cortex absent. Apothecia lecideine-type, immersed, sometimes aggregate, round or irregular; disc black, flat, less concave, margin reduced, sometimes slightly raised, often poorly developed in section, pruinose or not. Exciple almost absent, sometimes developed, brown. Hymenium colorless, paraphyses simple, rare branch, anastomosing or not; epihymenium brown, green or brown green, without epinecral layer; subhymenium colorless, sometimes pale brown; hypothecium pale brown to brown. Asci Porpidia-type, cylindrical, eight-spored; ascospores ellipsoid, halonate, non-amyloid. Pycnidia present or not, immersed, liner or stellate, black, margin pruinose; conidia bacilliform.

\section{Chemistry}

Thallus K-, C-. Medulla I+, K-, C-. Confluentic acid, often accompanied with 2'-0-methylmicophyllinic acid, planaic acid or no substances detected by TLC. The compound planaic acid is newly found in this genus.

\section{Ecology and distribution}

Growing on bare rock, sandstone or granite, from elevations of 3800 to $4500 \mathrm{~m}$ in the alpine zone of west China and elevations of 1200 to $1900 \mathrm{~m}$ in the steppe of north China. Worldwide distribution.

\section{Remarks}

Species with lecanorine apothecia were previously included in Immersaria (Calatayud and Rambold 1998, Valadbeigi et al. 2011), but the five-loci phylogenetic analysis excluded these species from Immersaria. This exclusion entails a restricted concept of the genus. Immersaria is defined by its orange brown, yellow brown, sometimes rusty colored thallus, the amyloid medulla, the wax glossy areolae with a pruinose margin, the black immersed lecideine apothecia with a reduced margin, the brown epihymenium and the Porpidia-type asci with eight halonate and non-amyloid ascospores. The members of this genus occur in alpine or steppe habitats.

Species of Sporastatia A. Massal. have frequently been misidentified as members of Immersaria because of field observations of their glossy areolae and the immersed lecideine apothecia. However, they are characterized by multispora and their radiated, yellow brown thallus. Also, Miriquidica Hertel \& Rambold often resembles Immersaria by its glossy areolae and the lecideine apothecia, but differs in its black brown thallus, its Lecanora-type asci with non-halonate ascospores and often containing miriquidic acid. The immersed apothecia of Immersaria may resemble Aspicilia A. Massal. and Acarospora A. Massal., but Aspicilia has a white or gray thallus, the Aspicilia-type asci with non-halonate ascospores; Acarospora has multispora and a convex thallus.

Although four known species, Immersaria carbonoidea (J.W. Thomson) Esnault \& Cl. Roux, I. fuliginosa Fryday, I. olivacea Calat. \& Rambold and I. usbekica, currently lack molecular data, we temporarily conserved them within the Immersaria due to their morphology, which corresponds to that of Immersaria. Morphological comparisons were based on high-resolution photographs of type materials and the original descriptions.

Immersaria athroocarpa (Ach.) Rambold \& Pietschm., in Rambold, Biblthca Lichenol. 34: 240 (1989). -Fig. 4a-e

\section{Type}

Sweden [no locality, no date, no collector], H9508237 (H-Ach - lectotype!). High-resolution photographs seen.

\section{Description}

Thallus areolate, yellow brown, orange brown, continuous, areolae $0.25-1.0 \mathrm{~mm}$ in diam., often convex, regular polygon, tends to be squamalose in the margin, epruinose; margin pruinose; prothallus black, not distinct, sometimes absent. Upper cortex $32.5 \mu \mathrm{m}$ thick, 
yellow brown granules pigmented; epinecral layer $7.5 \mu \mathrm{m}$ thick; algal layer $82.5 \mu \mathrm{m}$ thick, cells $8.0-10.0 \times 7.5 \mu \mathrm{m}$ in diam., round; lower cortex absent. Apothecia frequent, densely crowded, immersed, 0.3-1.3 mm in diam.; disc black, rare pruinose, flat, epruinose; margin reduced. Exciple sometimes developed, $25.0 \mu \mathrm{m}$ wide, brown. Hymenium 107.5-112.5 $\mu \mathrm{m}$ thick, colorless; paraphyses 1.0$2.0 \mu \mathrm{m}$ wide, branched, not anastomosing; epihymenium $25.0 \mu \mathrm{m}$ thick, brown, rare green; subhymenium $90.0 \mu \mathrm{m}$ thick, colorless; hypothecium pale brown to brown, sometimes absent. Asci Porpidia-type, cylindrical, eight-spored; ascospores 17.5-20.0 × 10.0 $\mu \mathrm{m}$ in diam., ellipsoid, halo. Pycnidia immersed, stellate, black, margin pruinose; conidia 7.5-10.0 × $1.0 \mu \mathrm{m}$ in diam., bacilliform.

Chemistry. Thallus K-, C-. Medulla I+, K-, C-. 『: Confluentic acid. 『: Unknown substance.

\section{Ecology and distribution}

Growing on granite in arid and semi-arid steppe habitats at elevations of 1217-1915 m. Worldwide distribution. This species is known from Inner Mongolia and Mt. Changbai (Hertel and Zhao 1982) of China.

\section{Remarks}

The lectotype grows on siliceous rock and contains several intact apothecia. The materials from Inner Mongolia are identical with the lectotype based on comparisons with high-resolution photographs and the description given by Hertel (1977). It is therefore treated as I. athroocarpa at present. Some Inner Mongolian materials contain an unknown substance but form a well-supported clade with other materials. I. athroocarpa is characterised by the convex, yellow brown areolae and the big sizes of ascospores. In this genus, only this species has ascospores up to $20.0 \mu \mathrm{m}$ long.

Immersaria usberkica is similar to I. athroocarpa in its brown thallus and dense apothecia, but differs in its flat areolae, the brown epihymenium and the presence of confluentic acid and gyrophoric acid. By comparing with high-resolution photographs and the original descriptions (Hertel 1977) of I. usberkica, we discovered that previous reports of this species from China (Zhang et al. 2015) were due to misidentification. It is known from Algeria, Iran, Spain and the USSR (Barbero et al. 1990).

Specimens examined (SDNU). CHINA, Inner Mongolia, Chifeng City, Balin Youqi, Hongshilazi, 1403.2 m elev., 44 $13^{\circ} \mathrm{N}, 118^{\circ} 44^{\prime} \mathrm{E}$, on rock, 2019, Ling Hu et al. SDNU20190035; Rongshen, Wangfengou, $1217.4 \mathrm{~m}$ elev., $44^{\circ} 16^{\prime} \mathrm{N}, 118^{\circ} 22^{\prime} \mathrm{E}$, Ling Hu et al. SDNU20190140, SDNU20190143; Erlinba, 1915.2 m elev., 44²6'N, 11841'E, Ling Hu et al. SDNU20190227.

Immersaria aurantia C.M. Xie \& Li S. Wang, sp. nov. - Fungal Names FN839738; Fig. 4f-j

\section{Etymology}

The epithet "aurantia" refers to the orange thallus.

\section{Type}

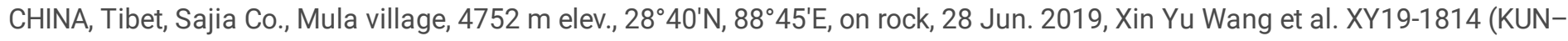
holotype).

\section{Description}

Thallus areolate, orange, dark orange, pale orange to pale red brown, continuous, areolae $0.75-1.25 \mathrm{~mm}$ in diam., flat, epruinose, irregular, margin thin pruinose; prothallus not seen. Upper cortex 25.0-45.0 $\mu \mathrm{m}$ thick, orange granules pigmented; epinecral layer 12.5-37.5-62.5 $\mu \mathrm{m}$ thick, uneven; algal layer 50.0-92.5 $\mu \mathrm{m}$ thick, cells 5.0-15.0 × 5.0-10.0 $\mu \mathrm{m}$ in diam., round; lower cortex absent. Apothecia frequent, scattered, immersed or isolated from areolae, 0.3-1.3 mm in diam.; disc black, flat or concave, sometimes pruinose; margin reduced. Exciple sometimes developed, $30.0 \mu \mathrm{m}$ wide, brown. Hymenium 55.0-82.5 $\mu \mathrm{m}$ thick, colorless; paraphyses 2.0-2.5 $\mu \mathrm{m}$ wide, only branched and anastomosing at apex; epihymenium 20.0 thick, green or green brown; subhymenium colorless, not distinct or absent; hypothecium brown. Asci Porpidia-type, cylindrical, eight-spored; ascospores 8.0$15.0 \times 5.0-7.5 \mu \mathrm{m}$ in diam., ellipsoid, halonate. Pycnidia rare, immersed, oblate, black, margin white; conidia $7.5 \times 1.0 \mu \mathrm{m}$ in diam., bacilliform. 
Chemistry. Thallus K-, C-. Medulla I+, K-, C-. 『: Confluentic acid, often accompanied with 2'-O-methylmicrophylinic acid. 叉:

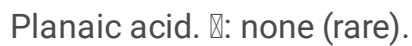

\section{Ecology and distribution}

Growing on rock at elevations of 3931-4229 $\mathrm{m}$ in the alpine zone. This species is known from Qinghai, Sichuan Province and Tibet of China.

Remarks: Immersaria aurantia is characterised by its distinct orange, irregular areolae and the mostly green epihymenium. I. athroocarpa and $I$. venusta are similar to $I$. aurantia, but $I$. athroocarpa differs in the convex, regular polygon areolae and the more crowded apothecia; I. venusta differs in having the yellow brown, often rusty, cracked areolae and the flat apothecia. Besides, confluentic acid and planiaic acid do not appear simultaneously in I. aurantia, whereas I. venusta always contains both of these two compounds together. The orange thallus of $I$. aurantia may resemble $I$. fuliginosa, but the latter differs in the black margin of areolae and the distinct thalliconidia.

Specimens examined (KUN). CHINA, Qinghai Province, Banma Co., $3933 \mathrm{~m}$ elev., 32 ${ }^{\circ} 40^{\prime} \mathrm{N}, 100^{\circ} 48^{\prime} \mathrm{E}$, on rock, 2020, Li-Song Wang et al. 20-66886, $3932 \mathrm{~m}$ elev., Li-Song Wang et al. 20-66897; Jiuzhi Co., Baiyu village, $4285 \mathrm{~m}$ elev., $33^{\circ} 14^{\prime} \mathrm{N}, 100^{\circ} 58^{\prime} \mathrm{E}$, Li-Song Wang et al. 20-67809. Sichuan Province: Rangtang Co., Mt. Haizi, $4223 \mathrm{~m}$ elev., $32^{\circ} 20^{\prime} \mathrm{N}, 101^{\circ} 25^{\prime} \mathrm{E}$, on rock, 2020, Li-Song Wang et al. 2066701, 4229 m elev., Li-Song Wang et al. 20-66693, 4217 m elev., Li-Song Wang et al. 20-66680, $4221 \mathrm{~m}$ elev., Li-Song Wang et al. 20-66692. Tibet, Changdu City, Mangkang Co., Luoni village, $4145 \mathrm{~m}$ elev., $29^{\circ} 56^{\prime} \mathrm{N}, 98^{\circ} 33^{\prime} \mathrm{E}$, on rock, 2020, Li-Song Wang et al. 2069091, 4138 m elev., Li-Song Wang et al. 20-69091, 20-69094; Gatuo town, 29³9'N, 98³5'E, 3831 m elev., Li-Song Wang et al. 2069114, 3850 m elev., Li-Song Wang et al. 20-69122; Gongga Co., Jiangtang town, 29¹2'N, 90³8'E, 2019.7.23, 4560 m elev., Xin-Yu

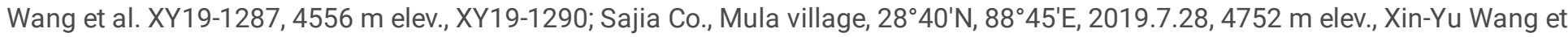
al. XY19-1814; Angren Co., Kerangla, $29^{\circ} 19^{\prime} \mathrm{N}, 87^{\circ} 01^{\prime} \mathrm{E}, 4530 \mathrm{~m}$ elev., Li-Song Wang et al. 19-63635.

Immersaria ferruginea C.M. Xie \& Li S. Wang, sp. nov. - Fungal Names FN839739; Fig. 5a-c

\section{Etymology}

The epithet "ferruginea" refers to the rusty brown color of the thallus.

\section{Type}

CHINA, Tibet, Changdu City, Mangkang Co., Quzika village, 4093 m elev., $29^{\circ} 15^{\prime} \mathrm{N}, 98^{\circ} 40^{\prime} \mathrm{E}$, on rock, 25 Sept. 2020, Li-Song Wang et al. 20-69144 (KUN-holotype).

\section{Description}

Thallus areolate, grayish brown, rusty colored, continuous, areolae $0.5-1.25 \mathrm{~mm}$ in diam., flat, less convex, rectangle to polygon, epruinose; margin pruinose; prothallus black, not distinct. Upper cortex 50.0-67.5 $\mu \mathrm{m}$ thick, brown granules pigmented; epinecral layer 17.5-40.0 $\mu \mathrm{m}$ thick; algal layer 75.0-77.5 $\mu \mathrm{m}$ thick, cells 4.0-7.5-13.0 × 4.0-7.5-13.0 $\mu \mathrm{m}$ in diam., round; lower cortex absent. Apothecia frequent, densely crowded, immersed, $0.75-1.25 \mathrm{~mm}$ in diam.; disc black, flat, pruinose; margin pruinose, slightly raised. Exciple sometimes developed, 25.0-27.5 $\mu \mathrm{m}$ wide, brown. Hymenium 57.5-100.0 $\mu \mathrm{m}$ thick, colorless; paraphyses 1.0-2.5 $\mu \mathrm{m} \mu \mathrm{m}$ wide, not branched, slightly anastomosing; epihymenium 15.0-32.5 $\mu \mathrm{m}$ thick, brown; subhymenium 25.0-62.5 $\mu \mathrm{m}$ thick, colorless to pale brown, rusty or dark pink; hypothecium pale brown. Asci Porpidia-type, cylindrical; ascospores not seen, or rarely seen. Pycnidia not seen.

\section{Chemistry}

Thallus K-, C-. Medulla I+, K-, C-. Confluentic acid, often accompanied with 2'-O-methylmicrophylinic acid.

\section{Ecology and distribution}

Growing on quartz sandstone or granite at elevations of 3848-4227 m in the alpine zone. This species is known from Sichuan Province and Tibet of China. 
Remarks: Immersaria ferruginea is characterized by its brown and rusty thallus, its densely crowded apothecia and its brown epihymenium. I. ferruginea and I. plumbeoolivacea were previously regarded as a single species, but it was later found that $I$. ferruginea grows on red sandstone whereas I. plumbeoolivacea grows on granite, and the thallus of I. ferruginea is rusty. The morphology of $I$. ferruginea resembles $I$. carbonoidea, but the latter differs in its dark black brown thallus, black brown hypothecium and content of norstictic acid.

Specimens examined (KUN). CHINA, Sichuan Province, Rangtang Co., Mt. Haizi, $4227 \mathrm{~m}$ elev., $32^{\circ} 20^{\prime} \mathrm{N}, 101^{\circ} 25^{\prime} \mathrm{E}$, on rock, 2020, LiSong Wang et al. 20-66697, 4221 m elev., Li-Song Wang et al. 20-67670. Tibet, Changdu City, Mangkang Co., Quzika village, $4093 \mathrm{~m}$ elev., $29^{\circ} 15^{\prime} \mathrm{N}, 98^{\circ} 40^{\prime} \mathrm{E}$, Li-Song Wang et al. 20-69144, 4101, Li-Song Wang et al. 20-69146, $4122 \mathrm{~m}$ elev., Li-Song Wang et al. 2069148; Gatuo town, $3848 \mathrm{~m}$ elev., $29^{\circ} 39^{\prime} \mathrm{N}, 98^{\circ} 35^{\prime} \mathrm{E}$, Li-Song Wang et al. 20-69105.

Immersaria plumbeoolivacea C.M. Xie \& Xin Y. Wang, sp. nov. - Fungal Names FN839740; Fig. 5d-f

\section{Etymology}

The epithet "plumbeoolivacea" refers to the lead brown thallus.

\section{Type}

CHINA, Qinghai Province, Banma Co., $3948 \mathrm{~m}$ elev., 3240'N, 10048'E, on rock, 9 Sept. 2020, Li-Song Wang et al. 20-66914 (KUNholotype).

\section{Description}

Thallus areolate, grayish brown, continuous, areolae 0.5-1.3 mm in diam., undulate, flat, convex or concave, irregular, epruinose; margin pruinose; prothallus black, not distinct. Upper cortex $40.0 \mu \mathrm{m}$ thick, brown granules pigmented; epinecral layer $30.0 \mu \mathrm{m}$ thick; algal layer $62.5 \mu \mathrm{m}$ thick, cells $10.0-15.0 \times 5.0-7.5 \mu \mathrm{m}$ in diam., round; lower cortex absent. Apothecia frequent, crowded, immersed, irregular, 0.75-1.75 mm in diam.; disc black, sometimes pruinose, flat; margin thin, pruinose, slightly raised. Exciple sometimes developed, 30.0-37.5 $\mu \mathrm{m}$ wide, brown. Hymenium 67.5-100.0 $\mu \mathrm{m}$ thick, colorless; paraphyses $2.0-2.5 \mu \mathrm{m}$ wide, not branched, slightly anastomosing; epihymenium $37.5 \mu \mathrm{m}$ thick, green or brown green; subhymenium 50.0-67.5 $\mu \mathrm{m}$ thick, colorless to pale brown, rusty or dark pink; hypothecium pale brown. Asci Porpidia-type, cylindrical; ascospores not seen. Pycnidia rare, immersed, oblate, black, margin pruinose; conidia $7.5 \times 1.0 \mu \mathrm{m}$ in diam., bacilliform.

\section{Chemistry}

Thallus K-, C-. Medulla I+, K-, C-. Confluentic acid, often accompanied with 2'-O-methylmicrophylinic acid.

\section{Ecology and distribution}

Growing on granite at elevations of 3932-3971 m in the alpine zone. This species is known from Qinghai Province of China.

Remarks: Immersaria plumbeoolivacea is characterized by its gray brown thallus, the areolae tend to be squamulose, with pruinose apothecia and green epihymenium. The phylogenetic results showed that I. ferruginea was a sister species to I. plumbeoolivacea, which is similar in its brown thallus and crowded apothecia, but differs in its thallus with rusty color and a brown epihymenium. The morphology of I. plumbeoolivacea resembles I. carbonoidea, but the latter has a black brown, thallus and contains traces of norstictic acid.

Specimens examined (KUN). CHINA, Qinghai Province, Banma Co., $3932 \mathrm{~m}$ elev., 32 $40^{\prime} \mathrm{N}, 100^{\circ} 48^{\prime} \mathrm{E}$, on rock, 2020, Li-Song Wang et al. 20-66889, 3948 m elev., Li-Song Wang et al. 20-66914, 3945 m elev., Li-Song Wang et al. 20-66915; Makehe, 3971 m elev., $32^{\circ} 42^{\prime} \mathrm{N}, 100^{\circ} 42^{\prime} \mathrm{E}$, Li-Song Wang et al. 20-67896.

Immersaria shangrilaensis C.M. Xie \& Lu L. Zhang, sp. nov. - Fungal Names FN839741; Fig. 6a-d

Etymology. The epithet "shangrilaensis" refers to the location at which the holotype was collected: "Shangri-La", a county of Yunnan Province in China. 
CHINA, Yunnan Province, Shangri-La County., Mt. Hong Shan, 4363 m elev., 287'N, 9954'E, on rock, 18 Aug. 2018, Li-Song Wang et al. 18-60447 (KUN-holotype).

\section{Description}

Thallus areolate, yellow brown, orange brown, often appears as grayish brown. It is generally heavily pruinose, continuous, 5.75$10.0 \mathrm{~cm}$ across, areolae aggregated by $4-14$ small areolae (often surrounded by black prothallus), small areolae up to $0.13 \mathrm{~mm}$ in diam., concave, or flat, irregular, pruinose; margin pruinose; prothallus black, distinct. Upper cortex 32.5-50.0 $\mu \mathrm{m}$ thick, yellow brown granules pigmented; epinecral layer 15.0-20.0 $\mu \mathrm{m}$ thick; algal layer 47.5-65.0 $\mu \mathrm{m}$ thick, cells 7.5-8.0 $\times 5.0 \mu \mathrm{m}$ in diam., round; lower cortex absent. Apothecia frequent, crowded, immersed or isolated from areolae, $0.38-0.75 \mathrm{~mm}$ in diam.; disc black, concave to flat, aggregated, crack once mature, thin pruinose; margin reduced, slightly raised. Exciple almost absent. Hymenium 100.0-137.5 $\mu \mathrm{m}$ thick, colorless; paraphyses $2.5 \mu \mathrm{m}$ wide, branched, anastomosing or not; epihymenium $15.0 \mu \mathrm{m}$ thick, brown; subhymenium $55.0 \mu \mathrm{m}$ thick, colorless; hypothecium colorless to pale brown, sometimes absent. Asci Porpidia-type, cylindrical, eight-spored; ascospores 7.0-9.0 × 3.0-4.0 $\mathrm{m}$, ellipsoid, halonate (sometimes not distinct). Pycnidia immersed, oblate, black, margin heavily pruinose; conidia $7.5 \times 1.0 \mu \mathrm{m}$, bacilliform.

\section{Chemistry}

Thallus K-, C-. Medulla I+, K-, C-. Confluentic acid, planaic acid and/or 2'-0-methylmicophyllinic acid.

\section{Ecology and distribution}

Growing on granite at elevations of $4361-4503 \mathrm{~m}$ in the alpine zone. This species is known from Yunnan Province of China.

\section{Remarks}

The materials of Immersaria athroocarpa from Shangri-La county of Yunnan Province are identical with the paratype Hertel (1977) reported from the same locality, but differ from the Lectotype in its aggregate areolae, the aggregate apothecia and the smaller size of ascospores (7.0-9.0 × 3.0-4.0 $\mu \mathrm{m})$. Based on the phenotypic and phylogenetic results, the materials from Shangri-La were treated as a new species, I. shangrilaensis. It is characterized by its large thallus, up to $10.0 \mathrm{~cm}$ in diam., the aggregate areolae and apothecia and the small size of ascospores.

\section{Specimens examined}

CHINA, Yunnan Province, Shangri-La Country, 4350-4500 m elev., on rock, 1915, Handel-Mazzetti no. $6945=$ WU-Lichenes0037752 (WU); Mt. Hong Shan, 4363 m elev., 28 ${ }^{\circ} 7^{\prime} \mathrm{N}, 9^{\circ} 54^{\prime} \mathrm{E}$, on rock, 2018, Li-Song Wang et al. 18-60430 (KUN), Li-Song Wang et al. 1860447 (KUN) 4503.1 m elev., Chun-Xiao Wang et al. SDNU20181696 (SDNU), 4361.9 m elev., Chun-Xiao Wang et al. SDNU20181675 (SDNU); Luquan Co., Mt. Jiaozixueshan, 3800 m elev., 2008, Hai-Ying Wang SDNU20082253 (SDNU); Lijiang City, Mt. Laojun, $26^{\circ} 37^{\prime} \mathrm{N}, 99^{\circ} 43^{\prime} \mathrm{E}, 2018,3981 \mathrm{~m}$, Li-Song Wang et al. 18-60555, 18-60602 (KUN).

Immersaria venusta C.M. Xie \& Xin Y. Wang, sp. nov. - Fungal Names FN839742; Fig. 6e-i

\section{Etymology}

The epithet "venusta" refers to the beautiful appearance of the thallus.

\section{Type}

CHINA, Qinghai Province, Maqing Co., Xueshan village, $4187 \mathrm{~m}$ elev., 34³7'N, 99²4'E, on rock, 11 Sept. 2020, Li-Song Wang et al. 20-67969 (KUN-holotype).

\section{Description}


Thallus areolate, brown, orange brown, more or less rusty, continuous, areolae $0.5-1.25 \mathrm{~mm}$ in diam., flat or slightly convex, irregular, tend to rectangular, often cracked, sometimes pruinose; margin pruinose; prothallus not seen. Upper cortex $37.5 \mu \mathrm{m}$ thick, yellow brown granules pigmented; epinecral layer $12.5 \mu \mathrm{m}$ thick; algal layer $127.5 \mu \mathrm{m}$ thick, cells 5.0-10.0 × 5.0-7.5 $\mu \mathrm{m}$ in diam., round; lower cortex absent. Apothecia frequent, crowded, immersed or isolated from areolae, $0.6-1.0 \mathrm{~mm}$ in diam.; disc black, flat, epruinose; margin reduced, sometimes developed. Exciple sometimes developed, $35.0 \mu \mathrm{m}$ wide, brown. Hymenium 92.5-112.5 $\mu \mathrm{m}$ thick, colorless; paraphyses $2.0 \mu \mathrm{m}$ wide, anastomosing; epihymenium 27.5-30.0 $\mu \mathrm{m}$ thick, brown; subhymenium $62.5 \mu \mathrm{m}$ thick, colorless; hypothecium brown. Asci Porpidia-type, cylindrical, eight-spored; ascospores 10.0-12.5 × 5.0-7.5 $\mu$ m, ellipsoid, halonate. Pycnidia immersed, linear, black, margin pruinose; conidia not seen.

Chemistry. Thallus K-, C-. Medulla I+, K-, C-. \: Confluentic acid, often accompanied with 2'-0-methylmicrophylinic acid. 邓: Planaic acid. 『: none (rare).

\section{Ecology and distribution}

Growing on quartz sandstone or granite at elevations of 3930-4256 m in the alpine zone. This species is known from Qinghai Province of China.

Remarks: Immersaria venusta is characterised by its yellow brown, cracked areolae, its flat apothecia and brown epihymenium. It resembles I. shangrilaensis by its cracked areolae, but its areolae have the tendency to split into several patches but not aggregate like those of I. shangrilaensis. I. athroocarpa is similar to I. venusta in the brown appearance of its thallus and in forming a sister group in the phylogenetic tree, but it differs in its yellow brown thallus, convex areolae, densely crowded apothecia and bigger ascospores $(17.5-20.0 \times 10.0 \mu \mathrm{m})$. This species is also similar to $I$. aurantia (see notes for $I$. aurantia). The brown thallus of $I$. venusta possibly resembles I. olivacea, but the latter differs in its simple or one-septate ascospores, pyriform conidia and dark bluish green epihymenium. Three specimens of I. venusta have brown thallus, which resembles I. plumbeoolivacea, but they have neatly arranged, thick areolae.

Specimens examined (KUN). CHINA, Qinghai Province, Maqing Co., Xueshan village, $4187 \mathrm{~m}$ elev., 34³7' $\mathrm{N}, 99^{\circ} 42^{\prime} \mathrm{E}$, on rock, 2020, Li-Song Wang et al. 20-67969, 20-67965; Banma Co., Yaertang village, $3930 \mathrm{~m}$ elev., 32²4' $\mathrm{N}, 100^{\circ} 42^{\prime} \mathrm{E}$, Li-Song Wang et al. 2066940. Sichuan Province, Shiqu Co., Xinrong village, $4043 \mathrm{~m}$ elev., $32^{\circ} 59^{\prime} \mathrm{N}, 98^{\circ} 19^{\prime} \mathrm{E}$, on rock, 2020, Li-Song Wang et al. 20-68802; Rangtang Co., Mt. Haizi, $4246 \mathrm{~m}$ elev., $32^{\circ} 21^{\prime} \mathrm{N}, 11^{\circ} 24^{\prime} \mathrm{E}$, Li-Song Wang et al. 20-66721, 20-66725.

Selected additional comparative material was examined.

Bellemerea alpina (Sommerf.) Clauzade \& Cl. Roux RUSSIA, Lps. Petsamo, Pummangin vuonon N-puoli, 1938, Räsänen, V., H9503269 (H-type!); Lps. Petsamo, inter Vaitolahti et Kervanto, 1938, Räsänen, V., H9503270 (H-type!).

Bellemerea cinereorufescens (Ach.) Clauzade \& Cl. Roux FINLAND, Ob. Simo. Anteroinen. Rantakivellä, 1920, Räsänen, V., H9503267 (H-type!); Le. Enontekiö, Kirkonkylä, 1925, Kari, L.E., H9503268 (H-type!).

Immersaria cupreoatra (Nyl.) Calatayud \& Rambold RUSSIA, KI. Kurkijoki, Kuuppala, Himohirsi, 1934, Räsänen, V., H9503417, H9510194 (H-type!).

High-resolution photographs seen.

Immersaria carbonoidea (J.W. Thomson) Esnault \& Cl. Roux USA, Alaska, along the Pitmegea River, 15 miles upstream from Cape Sabine, 1958, Thomson, J.W., M0082171 (M-Isotype!), G00126754 (G-isotype!).

Immersaria olivacea Calat. \& Rambold SPAIN, Espana, Castelló: Benicàssim, Parreta Alta, 390 m elev., 1993, Calatayud, V., M0101779 (M-isotype!).

Immersaria usbekica (Hertel) M. Barbero, Nav.-Ros. \& Cl. Roux ALGERIA, Algerie-Atlas Tellieu, Larba, Piste de Bougara á Tablat au SE de l'arboretum de Meindja, 1985, Esnault, J., M0101787 (M-paratype!).

Lecaimmeria C.M. Xie, Lu L. Zhang \& Li S. Wang, gen. nov. - Fungal Names FN839743; 


\section{Etymology}

The epithet "Lecaimmeria" refers to the immersed lecanorine apothecia of known species.

Type: Lecaimmeria orbicularis C.M. Xie \& Lu L. Zhang, sp. nov.

\section{Description}

Thallus crustose, red brown, orange brown or dark brown, continuous or not, areolae irregular or tend to rectangular, with wax glossy, margin white or black, prothallus distinct at the margin of thallus or absent, sometimes developed between areolae. Upper cortex with orange granules pigmented, epinecral layer colorless, algal layer continuous, medulla filled with gray granules, lower cortex absent. Apothecia lecanorine-type, immersed, round or irregular; disc red brown, dark red brown or dark orange brown, flat or concave, margin present or absent, black or white, rare green, pruinose or not. Exciple reduced, tissue at the lateral sides of the hymenium corresponding to the upper cortex and the algal layer of the vegetative areolae, and to hypothecial hyphal cells when apothecia reach the margin of the areole. Hymenium colorless, paraphyses simple, rare branch, anastomosing or not, epihymeinum orange, orange brown, rare brown, with epinecral layer. Asci Porpidia-type, cylindrical, eight-spored; ascospores ellipsoid, halonate, non-amyloid. Pycnidia present or absent, immersed, rare convex, liner or stellate, rare tuberculiform, conidia bacilliform.

\section{Chemistry}

Thallus K-, C-. Medulla I+, K-, C+/-. Gyrophoric acid, 4-O-demethylplanaic acid or no substances detected by TLC.

\section{Ecology and distribution}

Growing on rock, sandstone, granite or Qilian jade (rare), from elevations of 3100 to $4800 \mathrm{~m}$ in the alpine zone of west China and from 1200 to 1900 m in the steppe of north China. This genus is known from China, Europe, Iran, Macedonia, Mongolia, Romania and Russia.

\section{Remarks}

The five-loci phylogenetic analysis showed that these lecanorine apothecia species should be excluded from Immersaria and formed a novel lineage, thus they are here treated as a new genus Lecaimmeria. Lecaimmeria is distinguished from related genera by its glossy wax, orange or red brown areolae with margins, the amyloid medulla, the red brown immersed lecanorine apothecia with margins, the orange epihymenium with an epinecral layer and the Porpidia-type asci with eight halonate and non-amyloid ascospores. The genus is distributed in alpine areas, high altitude dessert-steppe areas or high latitude steppe. Almost all the species of Lecaimmeria grow on granite or sandstone, with the exception of one species, L. tuberculosa, which grows on jade. Interestingly, the margin of pycnidia and areolae of $L$. tuberculosa appear with heavily jade green pruinose.

The immersed apothecia and brown thallus of Lecaimmeria often resemble those of Immersaria, but Lecaimmeria differs in its red brown lecanorine apothecia, often with a white margin, their orange epihymenium with an epinecral layer and content of gyrophoric acid. This genus is often confused with Bellemerea in its lecanorine apothecia and the Porpidia-type asci with halonate ascospores, but the latter genus differs in its white thallus and amyloid ascospores.

Three species previously in Immersaria, I. cupreoatra, I. iranica and I. mehadiana, have lecanorine apothecia, but two of these, I. cupreoatra and I. mehadiana, currently lack molecular sequences. It is suggested that these three species should be transferred to Lecaimmeria, based on the following factors. Their morphology is consistent with Lecaimmeria according to molecular results and comparisons with type specimens, high-resolution photographs of the type materials and the original descriptions. One unknown "Immersaria" species from Macedonia is sister to L. iranica in the phylogenetic tree (Fig. 3), but differs in its black margin of areolae, absence of gyrophoric acid and comparison with high-resolution photograph and previous records (Malícek and Mayrhofer 2017). This unknown species with lecanorine apothecia is possibly a member of Lecaimmeria, but descriptions are lacking and the specimens were not seen. Thus, this species was temporarily retained in Immersaria.

Lecaimmeria botryoides C.M. Xie \& Li S. Wang, sp. nov. - Fungal Names FN839744; Fig. 7a-e 


\section{Etymology}

The epithet "botryoides" refers to the crowded apothecia while immature.

\section{Type}

CHINA, Sichuan Province, Aba City, Rangtang County, Haizi Mt., 4225 m elev., 32²1'N, 101²2'E, on rock, 6 Sept. 2020, Li-Song Wang et al. 20-66730 (KUN-holotype).

\section{Description}

Thallus areolate, red brown, discontinuous, areolae $0.25-1.0 \mathrm{~mm}$ in diam., flat, slightly concave or convex, pruinose, polygon, tend to be rectangular, margins with heavy pruinose. Prothallus black, distinct in the margin of thallus. Upper cortex 20.0-25.0 $\mu \mathrm{m}$ thick, brown; epinecral layer 22.5-47.5 $\mu \mathrm{m}$ thick; algal layer $37.5 \mu \mathrm{m}$ thick, cells 7.5-10.0 × 7.5-10.0 $\mu \mathrm{m}$ in diam., round; lower cortex absent. Apothecia frequent, irregular, densely crowded while immature (3-6/areolae), aggregate once mature, immersed, 0.25-1.25 $\mathrm{mm}$ in diam.; disc red brown, flat, or concave, epruinose; margin pruinose, slightly raised. Hymenium 67.5-100.0 (-155.0) $\mu \mathrm{m}$ thick, colorless; paraphyses $2.5 \mu \mathrm{m}$ wide, simple, only branched at the top, not anastomosing; epihymenium 25.0-30.0 $\mu \mathrm{m}$ thick, orange; epinecral layer 2.5-7.5 $\mu \mathrm{m}$ thick; subhymenium 17.5-37.5 $\mu \mathrm{m}$ thick, colorless; hypothecium colorless. Asci Porpidia-type, cylindrical, eight-spored; ascospores 7.5-8.0 × 4.0-6.0 $\mu \mathrm{m}$ in diam., ellipsoid, halonate. Pycnidia not seen; conidia not seen.

Chemistry: Thallus K-, C-. Medulla I+, K-, C+/-. 『: Gyrophoric acid. 『: none.

\section{Ecology and distribution}

Growing on rock at elevations of 3178-4300 $\mathrm{m}$ in the alpine zone. This species is known from Qinghai and Sichuan Province of China.

Remarks: Lecaimmeria botryoides is characterized by its discontinuous thallus, densely crowded apothecia while immature, and the orange epihymenium. L. orbicularis is similar to L. botryoides in its red brown thallus, but differs in its round, flat apothecia and continuous thallus. The red brown thallus of $L$. botryoides resembles $L$. cupreoatra, but the latter differs in its black margin of apothecia and its distinct black prothallus between areolae.

Specimens examined (KUN). CHINA, Qinghai Province, Banma Co., $3958 \mathrm{~m}$ elev., 32 $40^{\prime} \mathrm{N}, 100^{\circ} 48^{\prime} \mathrm{E}$, on rock, 2020, Li-Song Wang et al. 20-66900, $3932 \mathrm{~m}$ elev., Li-Song Wang et al. 20-66898, $3935 \mathrm{~m}$ elev., Li-Song Wang et al. 20-66891, $3178 \mathrm{~m}$ elev., Li-Song Wang et al. 20-66765. Sichuan Province, Rangtang Co., Mt. Haizi, 4256 m elev., 32²1'N, 101²4'E, on rock, 2020, Li-Song Wang et al. 2066721, 4300 m elev., Li-Song Wang et al. 20-67706, 4276 m elev., Li-Song Wang et al. 20-66706, 4255 m elev., Li-Song Wang et al. 20-66707, 4274 m elev., Li-Song Wang et al. 20-66713, 4274 m elev., Li-Song Wang et al. 20-66711, 20-66705, $4225 \mathrm{~m}$ elev., Li-Song Wang et al. 20-66730, $4220 \mathrm{~m}$ elev., $32^{\circ} 20^{\prime} \mathrm{N}, 101^{\circ} 25^{\prime} \mathrm{E}$, Li-Song Wang et al. 20-66683.

Lecaimmeria cupreoatra (Nyl.) C.M. Xie, comb. nov. - Fungal Names FN839745;

\section{Type}

RUSSIA, Ad Onegam, Medväschiigora, 1863, Simming, Th., H-NYL 25061 = H9508237 (H-lectotype!).

\section{Description}

Nylander (1866).

\section{Remarks}

The lectotype grows on siliceous rock and contains several intact apothecia. "Immersaria" cupreoatra has lecanorine apothecia and is related to I. Iygeae in its phylogeny, therefore it was transferred to Lecaimmeria. This species has not been recorded in China (see notes for L. mongolica). The species is known from Europe, Macedonia, Mongolia and Russia (Calatayud and Rambold 1998).

Lecaimmeria iranica (Valadb., Sipman \& Rambold) C.M. Xie, comb. nov. - Fungal Names FN839746;

Page 20/39 
IRAN, Mazandaran, Haraz road, $20 \mathrm{~km}$ to Aamol, $36^{\circ} 17^{\prime} \mathrm{N}, 52^{\circ} 21^{\prime} \mathrm{E}$, on calcareous rock, $1475 \mathrm{~m}, 7$ Apr. 2006, T. Valadbeigi 9008 (TARI-holotype; B, hb. Valadbeigi-isotype). Not seen.

\section{Description}

Valadbeigi et al. (2011).

\section{Remarks}

"Immersaria" iranica has lecanorine apothecia, a distinct epinecral layer and halonate ascospores (Valadbeigi et al. 2011). The materials from China are in accordance with the materials of Iran based on comparisons with the original descriptions and the photographs given by Valadbeigi et al. (2011). The characters of this species are consistent with the new genus and the phylogenetic results showed that it was clustered with species of Lecaimmeria. Therefore, it was transferred to Lecaimmeria. This species is currently known from Iran and China.

Specimens examined (SDNU). CHINA, Xinjiang, Urumqi, Mt. Tianshan-glacier No.1, alt. 3800 m, on rock, 2011, Z.L. Huang SDNU20126106, SDNU20129049.

Lecaimmeria lygaea C.M. Xie \& Lu L. Zhang, sp. nov. - Fungal Names FN839747; Fig. 7f-j

\section{Etymology}

The epithet "lygaea" refers to the dark appearance of the thallus.

\section{Type}

CHINA, Tibet, Changdu City, Mangkang County, Luoni Village, 4127 m elev., 2956'N, 98³3'E, on rock, 24 Sept. 2020, Li-Song Wang et al. 20-69072 (KUN-holotype).

\section{Description}

Thallus areolate, dark red brown, dark brown, continuous, areolae 0.5-1.0 mm, flat, epruinose, irregular pentagonal, sometimes rectangular, fissures between areolae often filled with black prothallus; margin black, thin pruinose; prothallus black, developed between areolae, also distinct in the margin. Upper cortex $20.0 \mu \mathrm{m}$ thick, orange brown granules pigmented; epinecral layer $15.0 \mu \mathrm{m}$ thick; algal layer $50.0 \mu \mathrm{m}$ thick, cells 7.5-12.5 × 7.5-12.5 $\mu \mathrm{m}$ in diam., round; lower cortex absent. Apothecia frequent, round, crowded, immersed, $0.25-0.75 \mathrm{~mm}$ in diam.; disc red brown, flat, or concave, epruinose; margin black, moderate thick, pruinose, raised. Hymenium 75.0-92.5 $\mu \mathrm{m}$ thick, colorless; paraphyses $2.0 \mu \mathrm{m}$ wide, simple, unbranched, not anastomosing; epihymenium 25.0-37.5 $\mu \mathrm{m}$ thick, orange brown; epinecral layer $7.5 \mu \mathrm{m}$ thick; subhymenium 20.0-25.0 $\mu \mathrm{m}$ thick, colorless; hypothecium absent. Asci Porpidia-type, cylindrical, eight-spored; ascospores 12.5-20.0 × 5.0-7.5 $\mu \mathrm{m}$ in diam., ellipsoid, halonate. Pycnidia immersed, stellate, black, margin pruinose; conidia $5.0 \times 1.0 \mu \mathrm{m}$ in diam., bacilliform.

\section{Chemistry}

Thallus K-, C-. Medulla I+, K-, C-. Unknown fatty acid.

\section{Ecology and distribution}

Growing on sandstone at elevations of $4095-4131 \mathrm{~m}$ in the alpine zone. This species is known from Tibet of China.

Remarks: Lecaimmeria lygaea is characterized by its dark brown thallus, black margin of its areolae, black prothallus which filled the fissures between areolae, dark orange apothecia and its orange brown epihymenium. L. cupreoatra and L. mehadiana are similar to L. lygaea, but L. cupreoatra has a discontinuous thallus, with each areola surrounded by black prothallus, dark red brown to black brown apothecia without margin. L. mehadiana has a white margin of areolae, black brown apothecia, brown 
epihymenium and contains 4-0-demethylplanaic acid. The phylogenetic results show that $L$. tibetica was a sister species to $L$. lygaea. They are similar in chemistry, but differ in its orange brown thallus and dark orange brown apothecia.

Specimens examined (KUN). CHINA, Tibet, Changdu City, Mangkang Co., Luoni village, $4099 \mathrm{~m}$ elev., $29^{\circ} 56^{\prime} \mathrm{N}, 98^{\circ} 33^{\prime} \mathrm{E}$, on rock, 2020, Li-Song Wang et al. 20-69054, 4131 m elev., Li-Song Wang et al. 20-69070, 4127 m elev., Li-Song Wang et al. 20-69072, 4095 m elev., Li-Song Wang et al.20-69053.

Lecaimmeria mehadiana (Calatayud \& Rambold) C.M. Xie, comb. nov. - Fungal Names FN839748;

\section{Type}

ROMANIA, Caras-Severin Comitat, Mehadía, Strájot Mtn., on rock, 1994, Rambold, G.W., M0101781 (M-holotype!), M0101780, M0101782, M0101783 (M-isotype!). High-resolution photographs seen.

\section{Description}

Calatayud and Rambold (1998).

\section{Remarks}

"Immersaria" mehadiana has lecanorine apothecia and is related to L. lygaea and L. cupreoatra in the appearance of dark brown thallus, therefore it has been transferred to Lecaimmeria. This species is characterized by its greyish prothallus, dark brown apothecia and the brown epihymenium. It is only known from Romania (Calatayud and Rambold 1998).

Lecaimmeria mongolica C.M. Xie \& Lu L. Zhang, sp. nov. - Fungal Names FN839749; Fig. 8a-e

\section{Etymology}

The epithet "mongolica" refers to the collection of the holotype within Inner Mongolia, an autonomous region of China.

Type: CHINA, Inner Mongolia: Chifeng City, Balinyouqi, Han Mountain, $1445 \mathrm{~m}$ elev., $44^{\circ} 11^{\prime} \mathrm{N}, 118^{\circ} 44^{\prime} \mathrm{E}$, on rock, 22 Jul. 2019 , Z.T. Zhao et al. SDNU20190354 (SDNU-holotype).

\section{Description}

Thallus areolate, orange, continuous, areolae $0.4-0.8 \mathrm{~mm}$ in diam., epruinose, neatly arranged, irregular, tend to be rectangular, margin pruinose; prothallus black, not distinct. Upper cortex $20.0 \mu \mathrm{m}$ thick, brown granules pigmented; epinecral layer 5.0-7.5 $\mu \mathrm{m}$ thick; algal layer $87.5 \mu \mathrm{m}$ thick, cells 7.5-12.5 × 7.5-12.5 $\mu \mathrm{m}$ in diam., round; lower cortex absent. Apothecia frequent, crowded, immersed or isolated from areolae, $0.25-0.75 \mathrm{~mm}$ in diam.; disc red brown, flat, slightly convex, epruinose; margin pruinose. Hymenium 62.5-82.5 $\mu \mathrm{m}$ thick, colorless; paraphyses $2.5 \mu \mathrm{m}$ wide, unbranched, not anastomosing; epihymenium $42.5 \mu \mathrm{m}$ thick, orange; epinecral layer 5.0-10.0 $\mu \mathrm{m}$ thick; subhymenium 30.0-37.5 $\mu \mathrm{m}$ thick, colorless; hypothecium absent. Asci Porpidia-type, cylindrical, eight-spored; ascospores 10.0-17.5 × 6.0-7.5 $\mu \mathrm{m}$ in diam., ellipsoid, halonate. Pycnidia immersed, oblate, rare ellipsoid, black, margin pruinose; conidia $5.0 \times 1.0 \mu \mathrm{m}$ in diam., bacilliform.

\section{Chemistry}

Thallus K-, C-. Medulla I+, K-, C-. Gyrophoric acid.

\section{Ecology and distribution}

Growing on granite at elevations of 1400-2000 m in steppe or mountains. This species is known from Inner Mongolia of China.

\section{Remarks}

This species was once reported as "Immersaria" cupreoatra from China (Zhang et al. 2015) but after comparing with the type materials this was found to be a misclassification. Also, the phylogenetic results showed that these materials formed a well- 
supported lineage belonging to Lecaimmeria. Therefore, here it has been treated as a new species, Lecaimmeria mongolica. It is characterized by its orange brown thallus, red brown apothecia with a distinct white margin and content of gyrophoric acid. $L$. cupreoatra resembles $L$. mongolica by containing gyrophoric acid, but it differs in its dark black brown thallus and the black margin of its apothecia. L. tibetica is similar to L. mongolica in its orange thallus, but differs in its smaller, dark orange apothecia and that no substance can be detected by TLC.

Specimens examined (SDNU). CHINA, Inner Mongolia: Chifeng City, Balin Youqi, Mt. Qingyangcheng, $1445 \mathrm{~m}$ elev., $43^{\circ} 35^{\prime} \mathrm{N}$, $117^{\circ} 30^{\prime} \mathrm{E}$, on rock, 2019, Zun-Tian Zhao et al. SDNU20190350; Han Shan, $1563 \mathrm{~m}$ elev., 44 ${ }^{\circ} 11^{\prime} \mathrm{N}, 118^{\circ} 44^{\prime} \mathrm{E}$, on rock, Zun-Tian Zhao et al. SDNU20190354; A'ershan City, Mt. Jiguan, 1500 m elev., on rock, 2011, Yu-Liang Cheng SDNU20124912, 1400 m elev., DaiFeng Jiang SDNU20124859; Ke Qi, Huanggangliang, 2000 m elev., on rock, Pan-Meng Wang SDNU20117613, Xing-Ran Kou SDNU20117399.

Lecaimmeria orbicularis C.M. Xie \& Lu L. Zhang, sp. nov. - Fungal Names FN839750; Fig. 9a-e

\section{Etymology}

The epithet "orbicularis" refers to the round shape of the apothecia.

\section{Type}

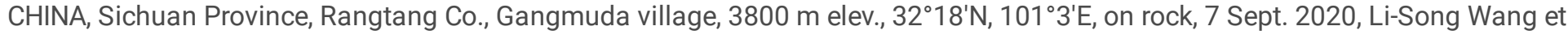
al. 20-66753 (KUN-holotype).

\section{Description}

Thallus areolate, red brown, rare orange brown, continuous, areolae $0.25-1.0 \mathrm{~mm}$, flat, occasionally wrinkled, tend to rectangular, fissures between areolae often filled with black prothallus, margin pruinose; prothallus black, developed between areolae, also distinct in the margin. Upper cortex 42.5-57.5 $\mu \mathrm{m}$ thick, brown granules pigmented; epinecral layer 5.0-20.0 $\mu \mathrm{m}$ thick; algal layer 70.0-112.5 $\mu \mathrm{m}$ thick, cells 10.0-15.0 × 7.5-10.0 $\mu \mathrm{m}$ in diam., round; lower cortex absent. Apothecia frequent, less crowded, immersed or isolated from areolae, $0.5-1.25 \mathrm{~mm}$ in diam.; disc red brown, flat, round, epruinose; margin white, slightly raised. Hymenium 75.0-112.5 $\mu \mathrm{m}$ thick, colorless; paraphyses $2.5 \mu \mathrm{m}$ wide, simple, unbranched, not anastomosing; epihymenium 17.5$30.0 \mu \mathrm{m}$ thick, orange; epinecral layer 5.0-15.0 $\mu \mathrm{m}$ thick; subhymenium 30.0-62.5 $\mu \mathrm{m}$ thick, colorless; hypothecium absent. Asci Porpidia-type, cylindrical, eight-spored; ascospores 12.5-15.0 × 5.0-6.0 $\mu \mathrm{m}$ in diam., ellipsoid, halonate. Pycnidia not seen.

\section{Chemistry}

Thallus K-, C-. Medulla I+, K-, C-. None.

\section{Ecology and distribution}

Growing on granite or sandstone at elevations of 3730-4200 $\mathrm{m}$ in the alpine zone. This species is known from Qinghai and Sichuan Provinces of China.

Remarks: Lecaimmeria orbicularis is characterized by its orange brown thallus, neatly arranged areolae, and round, flat apothecia. L. botryoides is similar to L. orbicularis (see notes for L. botryoides). L. mongolica might be confused with $L$. orbicularis due to its big apothecia with a white margin, but differs in its red brown thallus and distribution in steppes. The red brown thallus of $L$. cupreoatra resembles that of $L$. orbicularis, but differs in the black margin of its apothecia and its distinct black prothallus between areolae.

Specimens examined (KUN). CHINA, Qinghai Province, Jiuzhi Co., Nianbaoyuze, $4200 \mathrm{~m}$ elev., 33¹4'N, $100^{\circ} 58^{\prime} \mathrm{E}$, on rock, 2020, LiSong Wang et al. 20-66811, 20-66829, 20-66801, 20-66826A, 20-66821, 20-66805, 20-66833, 20-66817, 20-66841; Banma Co., Nianbaoyuze, $3930 \mathrm{~m}$ elev., 3240' $\mathrm{N}, 100^{\circ} 48^{\prime} \mathrm{E}$, Li-Song Wang et al. 20-66909, 20-66908, 20-66896, 20-66886B, 20-66899, 20-66935,

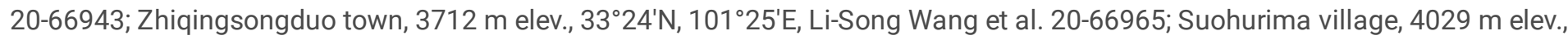
$33^{\circ} 23^{\prime} \mathrm{N}, 100^{\circ} 57^{\prime} \mathrm{E}$, Li-Song Wang et al. 20-66979. Sichuan Province, Rangtang Co., Gangmuda village, $3800 \mathrm{~m}$ elev., $32^{\circ} 18^{\prime} \mathrm{N}$, 
$101^{\circ} 3^{\prime} \mathrm{E}$, on rock, 2020, Li-Song Wang et al. 20-66753, 20-66750, $3793 \mathrm{~m}$ elev., Li-Song Wang et al. 20-66747, Shangrangtang village, $3730 \mathrm{~m}$ elev., $32^{\circ} 16^{\prime} \mathrm{N}, 101^{\circ} 21^{\prime} \mathrm{E}$, Li-Song Wang et al. 20-66743.

Lecaimmeria qinghaiensis C.M. Xie \& Li S. Wang, sp. nov. - Fungal Names FN839751; Fig. 9f-i

\section{Etymology}

The epithet "qinghaiensis" refers to the location in which the holotype was collected, in "Qinghai", a province of China.

\section{Type}

CHINA, Qinghai Province, Yushu City, Zaduo County, Sahuteng town, 4634 m elev., 3255' $\mathrm{N}, 95^{\circ} 46^{\prime} \mathrm{E}$, on rock, 20 Sept. 2020, Li-Song Wang et al. 20-68698 (KUN-holotype).

\section{Description}

Thallus areolate, yellow brown, rusty, continuous, areolae $0.5-1.5 \mathrm{~mm}$ in diam., flat, epruinose; margin pruinose, occasionally green pigmented; prothallus black, distinct at the margin. Upper cortex 27.5-37.5 $\mu \mathrm{m}$ thick, brown granules pigmented; epinecral layer 12.5-20.0 $\mu \mathrm{m}$ thick; algal layer 57.5-92.5 $\mu \mathrm{m}$ thick, cells 7.5-12.5 × 5.0-12.5 $\mu \mathrm{m}$ in diam., round; lower cortex absent. Apothecia frequent, immersed or isolated from areolae, round or somewhat irregular while immature, ellipsoid and tend to be rectangular for occupying the whole areolae once mature, $0.25-1.25 \mathrm{~mm}$ in diam.; disc brown, dark red brown, flat, occasionally with fissure when mature, epruinose; margin white, slightly raised. Hymenium 52.5-62.5 $\mu \mathrm{m}$ thick, colorless; paraphyses $2.0-2.5 \mu \mathrm{m}$ wide, unbranched, not anastomosing; epihymenium 25.0-30.0 $\mu \mathrm{m}$ thick, dark orange brown; epinecral layer 7.5-17.5 $\mu \mathrm{m}$ thick; subhymenium 50.0-62.5 $\mu \mathrm{m}$ thick, colorless; hypothecium absent. Asci Porpidia-type, cylindrical, eight-spored; ascospores 8.0$15.0 \times 5.0-7.5 \mu \mathrm{m}$ in diam., ellipsoid, halonate not distinct. Pycnidia rare, immersed, flat, slightly convex, liner, stellate, graphidoid once mature, black, margin pruinose; conidia not seen.

\section{Chemistry}

Thallus K-, C-. Medulla I+, K-, C-. None.

\section{Ecology and distribution}

Growing on rock at elevations of $4622-4815 \mathrm{~m}$ in the alpine zone. This species is known from Qinghai Province of China.

Remarks: Lecaimmeria qinghaiensis is characterized by the yellow brown, rusty thallus, the red brown apothecia often occupying the whole areolae at maturity, and the dark orange brown epihymenium. The phylogenetic results showed that $L$. tuberculosa was sister species to L. qinghaiensis which is similar in the appearance of thallus, but differs in the brown, never rusty thallus, the red brown apothecia, and the green, tuberculiform pycnidia. The red brown thallus of $L$. qinghaiensis resembles $L$. iranica, but differs in the rusty thallus and the white margin of apothecia.

Specimens examined (KUN). CHINA, Qinghai Province, Zaduo Co., Sahuteng town, $4634 \mathrm{~m}$ elev., 32 $55^{\prime} \mathrm{N}, 95^{\circ} 46^{\prime} \mathrm{E}$, on rock, 2020, LiSong Wang et al. 20-68698, $4637 \mathrm{~m}$ elev., Li-Song Wang et al. 20-68687, 4622 m elev., Li-Song Wang et al. 20-68696; $4790 \mathrm{~m}$ elev., $33^{\circ} 31^{\prime} \mathrm{N}, 95^{\circ} 8^{\prime} \mathrm{E}$, Xin-Yu Wang et al. 20-3115, $4791 \mathrm{~m}$ elev., Xin-Yu Wang et al. 20-3127; Zaqing village, $4815 \mathrm{~m}$ elev., Xin-Yu Wang et al. $20-849$.

Lecaimmeria tibetica C.M. Xie \& Xin Y. Wang, sp. nov. - Fungal Names FN839752; Fig. 10a-e

Etymology. The epithet "tibetica" refers to the location from which the holotype was collected: "Tibet", an autonomous region of China.

\section{Type}

CHINA, Tibet, Gongga Co., Jiangtang town, 4557 m elev., 29¹2'N, 90³8'E, on rock, 9 Sept. 2019, Xin-Yu Wang et al. XY19-1291 (KUN-holotype). 


\section{Description}

Thallus areolate, orange brown, epruinose, areolae $0.3-0.5 \mathrm{~mm}$ in diam., irregular, upper surface uneven, margin lacking, pruinose; prothallus black, distinct at the margin. Upper cortex 17.5-32.5 $\mu \mathrm{m}$ thick, brown granules pigmented; epinecral layer 10.0-20.0 $\mu \mathrm{m}$ thick; algal layer $75.0 \mu \mathrm{m}$ thick, cells 7.5-10.0 × 7.5-10.0 $\mu \mathrm{m}$ in diam., round; lower cortex absent. Apothecia rare, immersed or isolated from areolae, $0.25-0.5 \mathrm{~mm}$ in diam.; disc dark orange brown, epruinose, flat, slightly convex; margin pruinose. Hymenium 105.0-137.5 $\mu \mathrm{m}$ thick, colorless; paraphyses $2.5 \mu \mathrm{m}$ wide, unbranched, not anastomosing; epihymenium $25.0 \mu \mathrm{m}$ thick, orange; epinecral layer $12.5 \mu \mathrm{m}$ thick; subhymenium almost absent, colorless; hypothecium absent. Asci Porpidia-type, cylindrical, eightspored; ascospores 12.5-15.0 × 5.0-6.0 $\mu \mathrm{m}$ in diam., ellipsoid, halonate. Pycnidia immersed, oblate, black, margin pruinose; conidia $5.0 \times 1.5-2.0 \mu \mathrm{m}$ in diam., bacilliform.

\section{Chemistry}

Thallus $\mathrm{K}-, \mathrm{C}-$. Medulla I+, K-, C-. None.

\section{Ecology and distribution}

Growing on quartz sandstone at elevations of $4310-4583 \mathrm{~m}$ in the alpine zone. This species is known from Tibet of China.

Remarks: Lecaimmeria tibetica is characterized by the orange brown thallus, the black pigmented of areolae margin, and the dark orange brown and small size of apothecia. L. tibetica is similar to L. mongolica (see notes for $L$. mongolica). The red brown apothecia of $L$. cupreoatra resembles $L$. tibetica, but differs in its dark red brown thallus and the presence of gyrophoric acid.

Specimens examined (KUN). CHINA, Tibet, Gongga Co., Jiangtang town, $4583 \mathrm{~m}$ elev., $29^{\circ} 12^{\prime} \mathrm{N}, 90^{\circ} 38^{\prime} \mathrm{E}$, on rock, 2019 , Xin-Yu Wang et al. XY19-1288, 4557 m elev., XY19-1291, 4560 m elev., XY19-1280; Dingri Co., Zhaguozhong, $4310 \mathrm{~m}$ elev., 28³5'N, 8653'E, LiSong Wang et al. 19-64071.

Lecaimmeria tuberculosa C.M. Xie \& Xin Y. Wang, sp. nov. - Fungal Names FN839754; Fig. 10f-i

\section{Etymology}

The epithet "tuberculosa" refers to the tuberculiform of the pycnidia.

\section{Type}

CHINA, Gansu Province, Zhangye City, Sunan Co., Along the way from Sunan to Qilian, $3928 \mathrm{~m}$ elev., $38^{\circ} 37^{\prime} \mathrm{N}, 99^{\circ} 28^{\prime} \mathrm{E}$, on rock, 30 May 2018, Li-Song Wang et al. 18-58865 (KUN-holotype).

\section{Description}

Thallus areolate, red brown, continuous, areolae $0.5-1.25 \mathrm{~mm}$ in diam., slightly convex, epruinose; margin pruinose, often with jade green pigmented; prothallus not distinct. Upper cortex $27.5 \mu \mathrm{m}$ thick, orange granules pigmented; epinecral layer up to $27.5 \mu \mathrm{m}$ thick, uneven, sometimes absent; algal layer $50.0 \mu \mathrm{m}$ thick, cells 6.0-10.0 × 6.0-10.0 $\mu \mathrm{m}$ in diam., round; lower cortex absent. Apothecia frequent, scattered, immersed, 0.3-0.6 mm in diam.; disc red brown, concave, epruinose; margin absent. Hymenium 55.0-82.5 $\mu \mathrm{m}$ thick, colorless; paraphyses $2.5 \mu \mathrm{m}$ wide, unbranched, not anastomosing; epihymenium 15.0-30.0 $\mu \mathrm{m}$ thick, orange; epinecral layer $5.0 \mu \mathrm{m}$ thick, discontinuous; subhymenium $37.5 \mu \mathrm{m}$ thick, colorless; hypothecium colorless. Asci Porpidia-type, cylindrical, eight-spored; ascospores 6.0-12.5 × 3.0-5.0 $\mu \mathrm{m}$ in diam., ellipsoid, halonate. Pycnidia stellate, strongly convex, rarely immersed, forming tuberculiform, black, margin pruinose, with jade green pigmented; conidia 3.0-4.5 × $1.0 \mu \mathrm{m}$ in diam., oblong to bacilliform

\section{Chemistry}

Thallus K-, C-. Medulla I+, K-, C-. None.

\section{Ecology and distribution}


Growing on the Qilian jade or sandstone at elevations of 3928-4124 m in the alpine zone. This species is known from Qinghai Province and Gansu Province of China.

Remarks: Lecaimmeria tuberculosa is characterized by its red brown thallus, the jade green pruinose at the margin of its areolae, its red brown, concave apothecia without a proper margin and tuberculiform pycnidia. L. qinghaiensis is similar to L. tuberculosa (see notes for L. qinghaiensis). L. tuberculosa usually grows on jade, and interestingly the margin of pycnidia and areolae of the species are heavily jade green pigmented. $L$. iranica resembles $L$. tuberculosa by the absence of apothecia margin, but differs in its immersed pycnidia and white margin of its areolae.

Specimens examined (KUN). CHINA, Qinghai Province, Gande Co., Qingzhen village, $4124 \mathrm{~m}$ elev., $34^{\circ} 11^{\prime} \mathrm{N}, 100^{\circ} 12^{\prime} \mathrm{E}$, on rock, 2020 , Li-Song Wang et al. 20-68077, $4145 \mathrm{~m}$ elev., Li-Song Wang et al. 20-68055. Gansu Province, Zhangye City, Sunan Co., along the way from Sunan to Qilian, $3928 \mathrm{~m}$ elev., $38^{\circ} 37^{\prime} \mathrm{N}, 9^{\circ} 28^{\prime} \mathrm{E}$, on rock, 2018, Li-Song Wang et al. 18-58856, 18-58857, 18-58865, 18-59835.

\section{Key to Lecaimmeria and allied genera}

1 Apothecia lecanorine-type. .................................... 2

Apothecia lecideine-type. ..................................... 5

2 Apothecia adnate; Isidia spherical. .............................Koerberiella

Apothecia immersed; Isidia absent. ................................. 3

3 Thallus surface wax glossy, orange or red brown. ................... Lecaimmeria

Thallus surface not glossy, white. ............................... 4

4 Asci Aspicilia-type, ascospores non-halonate. ........................ . Aspicilia

Asci Porpidia-type, ascospores halonate, amyloid. ...................... Bellemerea

5 Epinecral layer absent. .............................................. 6

Epinecral layer present. ....................................... 8

6 Asci Lecanora-type; often containing miriquidic acid. .................. Miriquidica

Asci not Lecanora-type; not containing miriquidic acid. ...................... .

7 Asci Lecidea-type, ascospores non-halonate. ... .......................... . Lecidea

Asci Porpidia-type, ascospores halonate. ........................... Porpidia

8 Thallus surface dark brown; Asci Lecanora-type, ascospore non-halonate. .. ... . . . Miriquidica

Thallus surface orange or red brown; Asci Porpidia-type, ascospores halonate. .. . . Immersaria

\section{Key to species of Immersaria in this study}

1 Thallus grayish brown; Apothecia crowded. .............................

Thallus reddish brown; Apothecia rarely crowded. .......................... .

2 Thallus rusty; Apothecia over $1.3 \mathrm{~mm}$ in diam.; Epihymenium brown; growing on red sandstone. ................ I. ferruginea

Thallus never rusty; Apothecia never over $1.3 \mathrm{~mm}$ in diam.; Epihymenium green; growing on granite. .. I. plumbeoolivacea 
3 Thallus orange, areolae irregular. I. aurantia

Thallus not orange, areolae irregular, polygon or rectangle. 4

4 Thallus up to $10 \mathrm{~cm}$ across, areolae aggregated by several smaller areolae and black prothallus. .l. shangrilaensis

Thallus not up to $10 \mathrm{~cm}$ across, areolae not aggregated. .5

5 Thallus areolae convex, not rusty, not cracked; Ascospores over $15 \mu \mathrm{m}$ long. ... . I. athroocarpa

Thallus areolae flat, often rusty, cracked; Ascospores never over $15 \mu \mathrm{m}$ long.. ...... I. venusta

Key to species of Lecaimmeria in this study

1 Prothallus distinct and filled the fissures between areolae. .2

Prothallus only distinct at the margin. 4

2 Areolae margin white; Apothecia black brown; containing 4-0-demethylplanaic acid.

........ L. mehadiana

Areolae margin black; Apothecia dark red brown; containing gyrophoric acid or no substance detected by TLC. ....

.............................. 3

3 Thallus discontinuous, prothallus continuous, distinct and encircle every areolae; Apothecia dark red brown, margin absent. ... L. cupreoatra

Thallus continuous, prothallus discontinuous, not encircle every areolae; Apothecia dark orange, margins present. $\ldots \ldots \ldots \ldots \ldots \ldots \ldots \ldots \ldots \ldots \ldots$..... lygaea

4 Thallus orange. $\ldots \ldots \ldots \ldots \ldots \ldots \ldots \ldots \ldots \ldots \ldots \ldots \ldots \ldots \ldots \ldots \ldots \ldots .5$

Thallus reddish brown. $\ldots \ldots \ldots \ldots \ldots \ldots \ldots \ldots \ldots \ldots \ldots \ldots \ldots \ldots \ldots \ldots \ldots 6$

5 Apothecia red brown; containing gyrophoric acid. ...................... mongolica

Apothecia dark orange; no substance detected by TLC. . . ................. L. tibetica

6 Apothecia margin absent. ........................................ 7

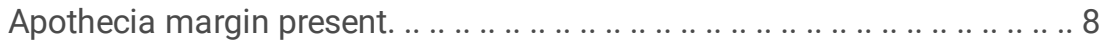

7 Areolae margin white; Epihymenium brown; Pycindia immersed, liner or stellate.. .. . L. iranica

Areolae margin green; Epihymenium orange; Pycindia convex, tuberculiform. . .L. tuberculosa

8 Thallus rusty; Apothecia occupy the whole areolae. L. qinghaiensis

Thallus not rusty; Apothecia do not occupy the areolae. .9

9 Apothecia irregular, crowded while immature, aggregate when mature. L. botryoides

Apothecia round, rarely crowded, not aggregate. L. orbicularis

\section{Declarations}

\section{Acknowledgments}

Page 27/39 
We are very grateful to Dr. Saara Velmala and Dr. Leena Myllys from the University of Helsinki $(H)$ and Dr. Water Till from the Universität Wien (WU) for the loan of type materials, and to Dr. Fiona Worthy, a post-doctoral from Kunming Institute of Botany, Centre for Mountain Ecosystem Studies, for careful correcting in English.

\section{Authors' contributions}

The manuscript was initially drafted by C.M. Xie, X.Y. Wang and L.L. Zhang. The authors commented on the draft in several rounds and provided substantial modifications. All authors read and approved the final manuscript.

\section{Funding}

This study was supported by the National Natural Science Foundation of China (31750001, 31970022), the Second Tibetan Plateau Scientific Expedition and Research Program (STEP) (2019QZKK0503) and the Youth Innovation Promotion Association CAS (2020388).

\section{Availability of data and materials}

All sequence data generated for this study (Table 1) can be accessed via GenBank: https://www.ncbi.nlm.nih.gov/genbank/.

\section{Declarations}

\section{Ethics approval and consent to participate}

Not applicable.

\section{Consent for publication}

Not applicable.

\section{Competing interests}

The authors declare they have no competing interests.

\section{Author details}

1 Key Laboratory of Plant Stress Research, College of Life Sciences, Shandong Normal University, Jinan, Shandong, 250014, China; corresponding authors email to: 612038@sdnu.edu.cn, wangxinyu@mail.kib.ac.cn

2 Key Laboratory for Plant Diversity and Biogeography of East Asia, Kunming Institute of Botany, CAS, Heilongtan, Kunming, Yunnan, 650204, China.

3 Institute of Environment and Ecology, Shandong Normal University, Jinan, Shandong, 250014, China.

\section{References}

1. Barbero M, Navarro-Rosinés P, Roux C (1990) Immersaria usbekica (Hertel) Barbero, Nav.-Ros. Et Roux comb. nov.[= Amygdalaria tellensis Esnault et Roux] nove trovita en Europo. Bulletin de la Société Linéenne de Provence 41: 139-142.

2. Buschbom J, Mueller G (2004) Resolving evolutionary relationships in the lichen-forming genus Porpidia and related allies (Porpidiaceae, Ascomycota). Molecular Phylogenetics and Evolution 32: 66-82.

3. Calatayud V, Rambold G (1998) Two new species of the lichen genus Immersaria (Porpidiaceae). Lichenologist 30: 231-244.

4. Clauzade G, Roux C (1984) Les genres Aspicilia Massal. et Bellemerea Hafellner \& Roux. Bulletin de la Société Botanique du Centre-Ouest 15:127-141.

5. Fryday AM, Hertel H (2014) A contribution to the family Lecideaceae s. lat. (Lecanoromycetidae inc. sed., lichenized Ascomycota) in the southern subpolar region; including eight new species and some revised generic circumscriptions. Lichenologist 46(3): 389-412. 
6. Fryday AM, Printzen C, Ekman S (2014) Bryobilimbia, a new generic name for Lecidea hypnorum and closely related species. Lichenologist 46(1): 25-37.

7. Hertel H, Zhao CF (1982) Lichens from Changbai Shan-some additions to the lichen flora of northeast China. Lichenologist 14: $139-152$.

8. Hertel H (1977) Gesteinsbewohnende Arten der Sammelgattung Lecidea (Lichenes) aus Zentral-, Ost- und Sudasien. Khumbu Himal, Ergebnisse des Forschungsunternehmens Nepal Himalaya 6: 145-458.

9. Huelsenbeck JP, Ronquist F (2001) MRBAYES: Bayesian inference of phylogenetic trees. Bioinformatics 17: 754-755.

10. Lanfear R, Frandsen PB, Wright AM, Senfeld T, Calcott B (2017) PartitionFinder 2: new methods for selecting partitioned models of evolution for molecular and morphological phylogenetic analyses. Molecular Biology and Evolution 34(3), 772-773.

11. Larena I, Salazar O, Gonzalez V, Julian MC, Rubio V (1999) Design of a primer for ribosomal DNA internal transcribed spacer with enhanced specificity for ascomycetes. Journal of Biotechnology 75(2-3): 187-194.

12. Liu YJ, Whelen S, Hall BD (1999) Phylogenetic relationships among ascomycetes: evidence from an RNA polymerase II subunit. Molecular Biology and Evolution 16(12): 1799-1808.

13. Lücking R, Hodkinson BP, Leavitt SD (2017) The 2016 classification of lichenized fungi in the Ascomycota and Basidiomycota-approaching one thousand genera. Bryologist 119: 361-416.

14. Malíček J, Mayrhofer H (2017) Additions to the lichen diversity of Macedonia (FYROM) [Ergänzungen zur Flechtendiversität von Makedonien (FYROM)]. Herzogia 30(2): 431-444.

15. Matheny PB, Liu YJ, Ammirati JF, Hall BD (2002) Using RPB1 sequences to improve phylogenetic inference among mushrooms (Inocybe, Agaricales). American Journal of Botany 89: 688-698.

16. McCune B, Curtis MJ, Di Meglio J (2017) New taxa and a case of ephemeral spore production in Lecideaceae from western North America. The Bryologist. 120(2):115-124.

17. Nylander W (1866) Lichenes Lapponiae orientalis. Notiser ur Sällskapets pro Fauna et Flora Fennica Förhandlingar 8:101-192.

18. Orange A, James PW, White FJ (2010) Microchemical methods for the identification of lichens. 2nd edn. London: British Lichen Society.

19. Rambaut A (2012) FigTree, v. 1.4.0. Institute of Evolutionary Biology, University of Edinburgh.

20. Rambold GA (1989) A monograph of the Saxicolous Lecideoid Lichens of Australia (excl. Tasmania). Bibliotheca Lichenologica 34: 239-240.

21. Rehner SA, Samuels GJ (1994) Taxonomy and phylogeny of Gliocladium analysed from nuclear large subunit ribosomal DNA sequences. Mycological Research 98: 625-634.

22. Stiller JW, Hall BD (1997) The origin of red algae: Implications for plastid evolution. PNAS 94: 4520-4525.

23. Valadbeigi T, Sipman H, Rambold G (2011) The genus Immersaria (Lecideaceae) in Iran, including I. iranica sp. nov. Lichenologist 43(3): 203-208.

24. Vilgalys R, Hester M (1990) Rapid genetic identification and mapping of enzymatically amplified ribosomal DNA from several Cryptococcus species. Journal of Bacteriology 172: 4239-4246.

25. White T, Bruns T, Lee S, Taylor F, White TJ, Lee SH, Taylor L, Shawetaylor J (1990) Amplification and direct sequencing of fungal ribosomal RNA genes for phylogenetics. In: Innis M, Gel-fand J, Sainsky J, et al. (eds), PCR Protocols: A Guide to Methods and Applications. Academic Press, San Diego: 315-322.

26. Zhang LL, Hu L, Zhao XX, Zhao ZT (2015) New records of Clauzadea and Immersaria from china. Mycotaxon -Ithaca Ny-, 130 (3)(3): 899-905.

27. Zoller S, Scheidegger C, Sperisen C (1999) PCR primers for the amplification of mitochondrial small subunit ribosomal DNA of lichen-forming ascomycetes. Lichenologist 31(5): 511-516.

\section{Figures}




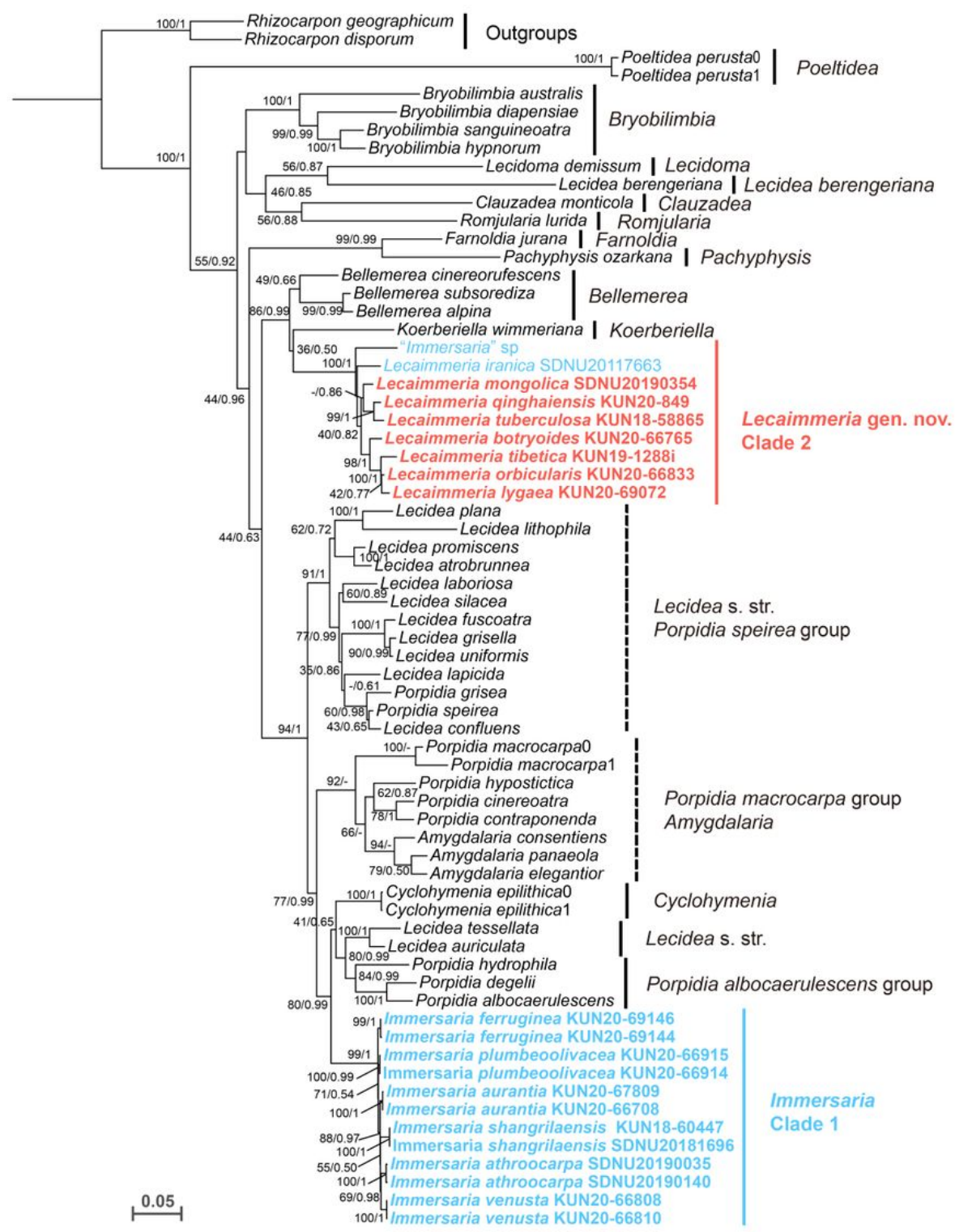

\section{Figure 1}

Phylogenetic tree constructed from Maximum likelihood analyses in Lecideaceae based on the concatenated nrITS-nrLSU-RPB1RPB2-mtSSU dataset. Maximum likelihood bootstrap probabilities above 40\% (left) and Bayesian inference posterior probabilities above 0.7 (right) are given at the nodes. 


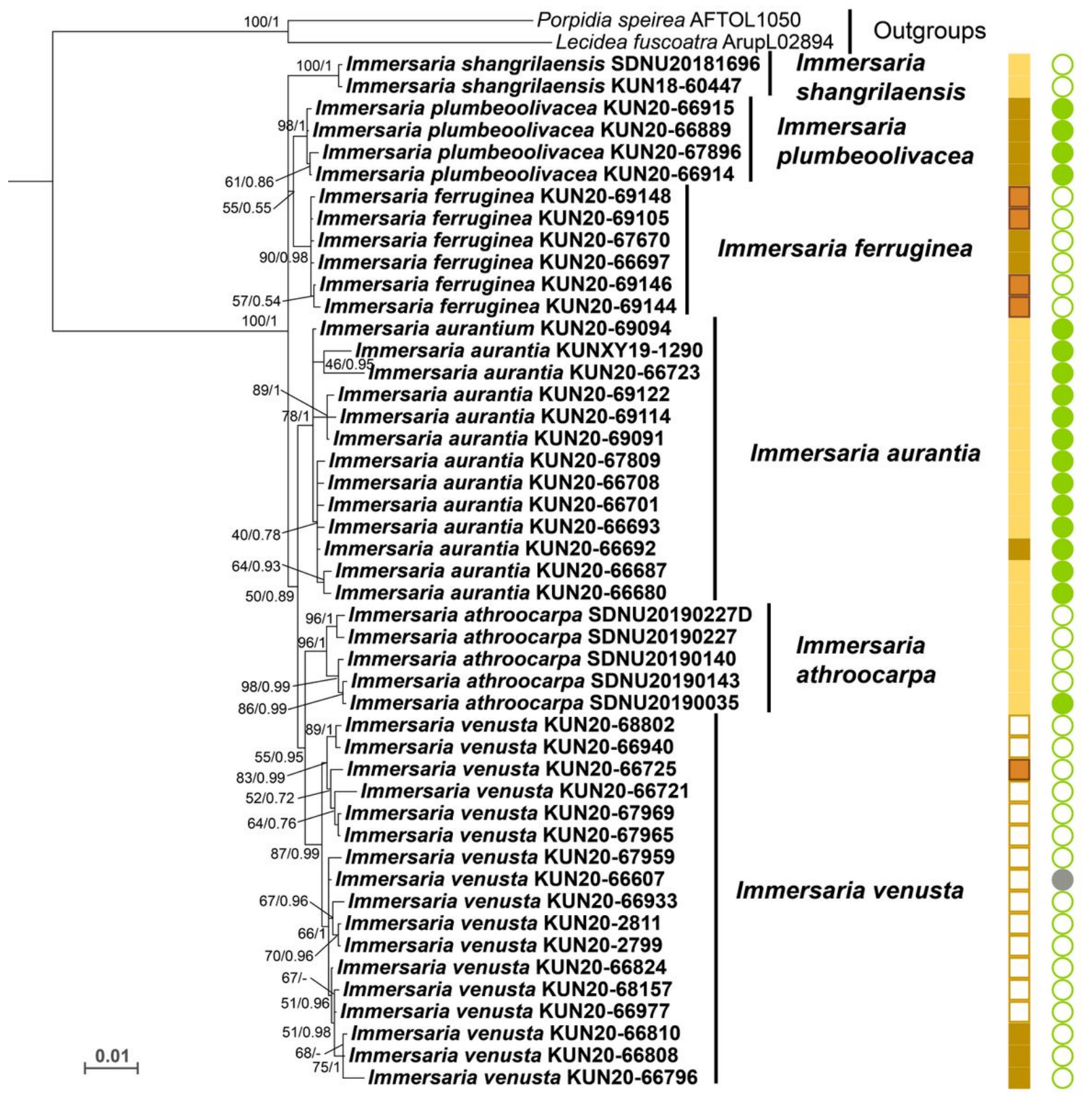

Figure 2

Phylogenetic tree constructed from Maximum likelihood analyses in Immersaria based on the concatenated nrITS-nrLSU-RPB1RPB2 dataset. Maximum likelihood bootstrap probabilities above $40 \%$ (left) and Bayesian inference posterior probabilities above 0.7 (right) are given at the nodes. Solid brown rectangle: thallus brown; solid orange rectangle: thallus yellow brown to orange brown; solid red rectangle: thallus rusty; hollow brown rectangle: thallus pale yellow brown. Solid green circle: green epihymenium; solid gray circle: without apothecia; hollow green circular: brown epihymenium. 


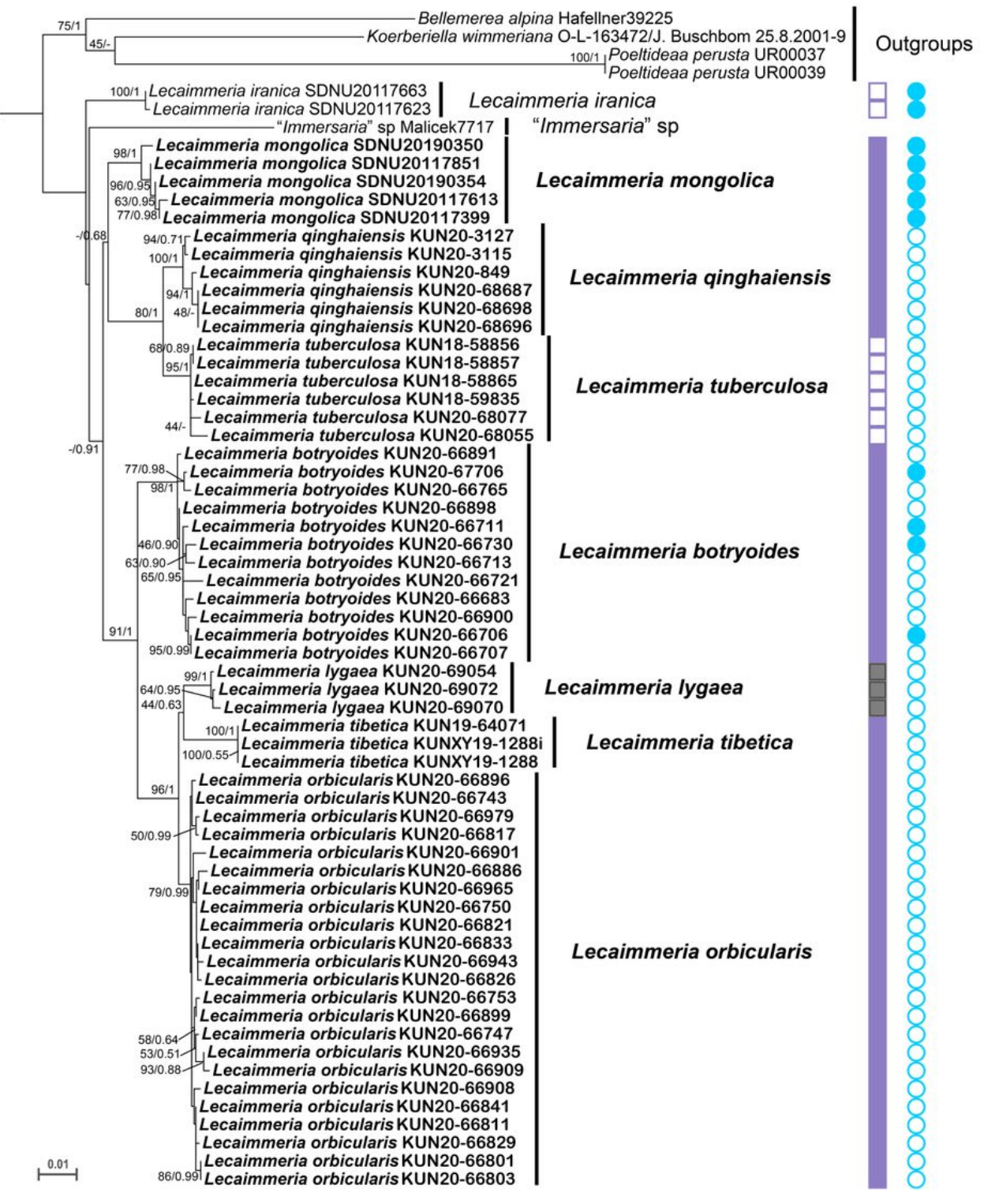

Figure 3

Phylogenetic tree constructed from Maximum likelihood analyses in Lecaimmeria based on the concatenated nrlTS-nrLSU-RPB1RPB2 dataset. Maximum likelihood bootstrap probabilities above $40 \%$ (left) and Bayesian inference posterior probabilities above 0.7 (right) are given at the nodes. Solid purple rectangle: areolae margin white; solid gray rectangle: areolae margin black; hollow purple rectangle: areolae margin jade green pigmented. Solid blue circle gyrophoric acid; hollow blue circle: none. 


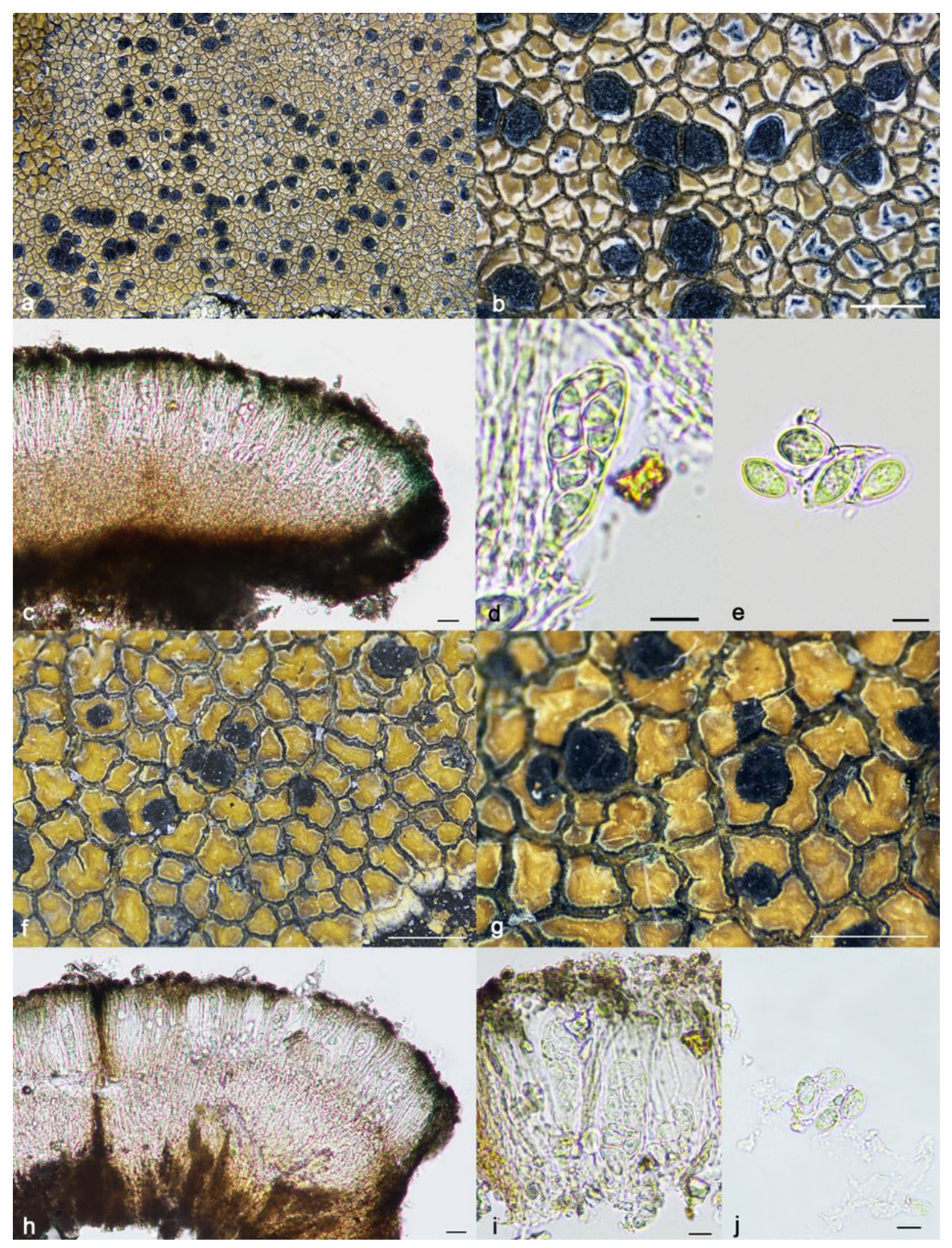

\section{Figure 4}

Immersaria athroocarpa (a-e SDNU20190227). a-b. Thallus; c. Apothecial anatomy; d. Ascus; e. Ascospores. I. aurantia (f-j KUN XY19-1290). f-g. Thallus; h. Apothecial anatomy; i. Asci; j. Ascospores. - Scale bars: a, b, f, g = $1 \mathrm{~mm} ; \mathrm{c}, \mathrm{h}=20 \mu \mathrm{m} ; \mathrm{d}, \mathrm{e}, \mathrm{i}, \mathrm{j}=10$ $\mu \mathrm{m}$. 


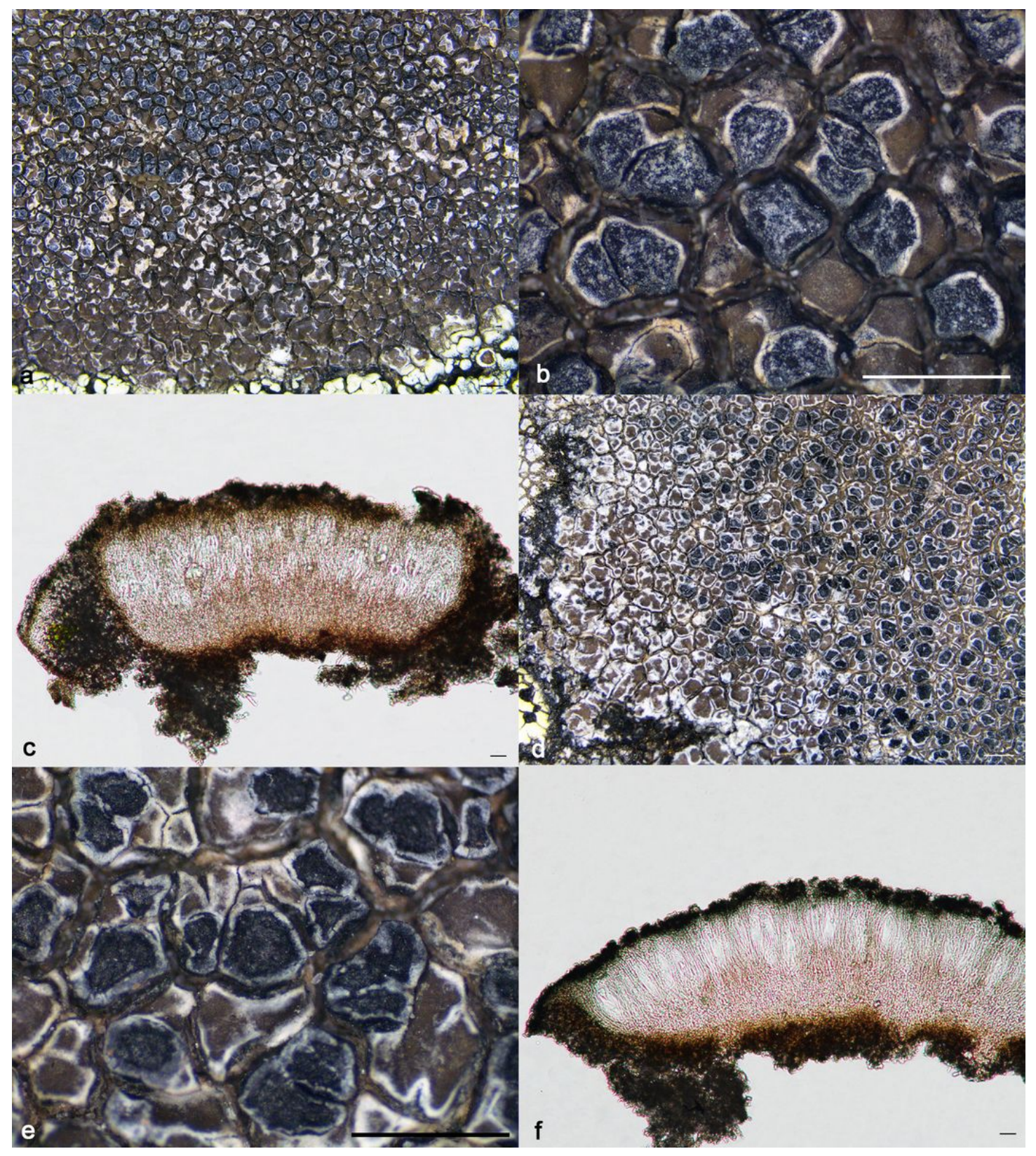

Figure 5

Immersaria ferruginea (a-c KUN 20-69144). a-b. Thallus; c. Apothecial anatomy. I. plumbeoolivacea (d-f KUN 20-66914). d-e. Thallus; $f$. Apothecial anatomy. - Scale bars: $a-b, d-w=1 \mathrm{~mm} ; c, f=20 \mu \mathrm{m}$. 


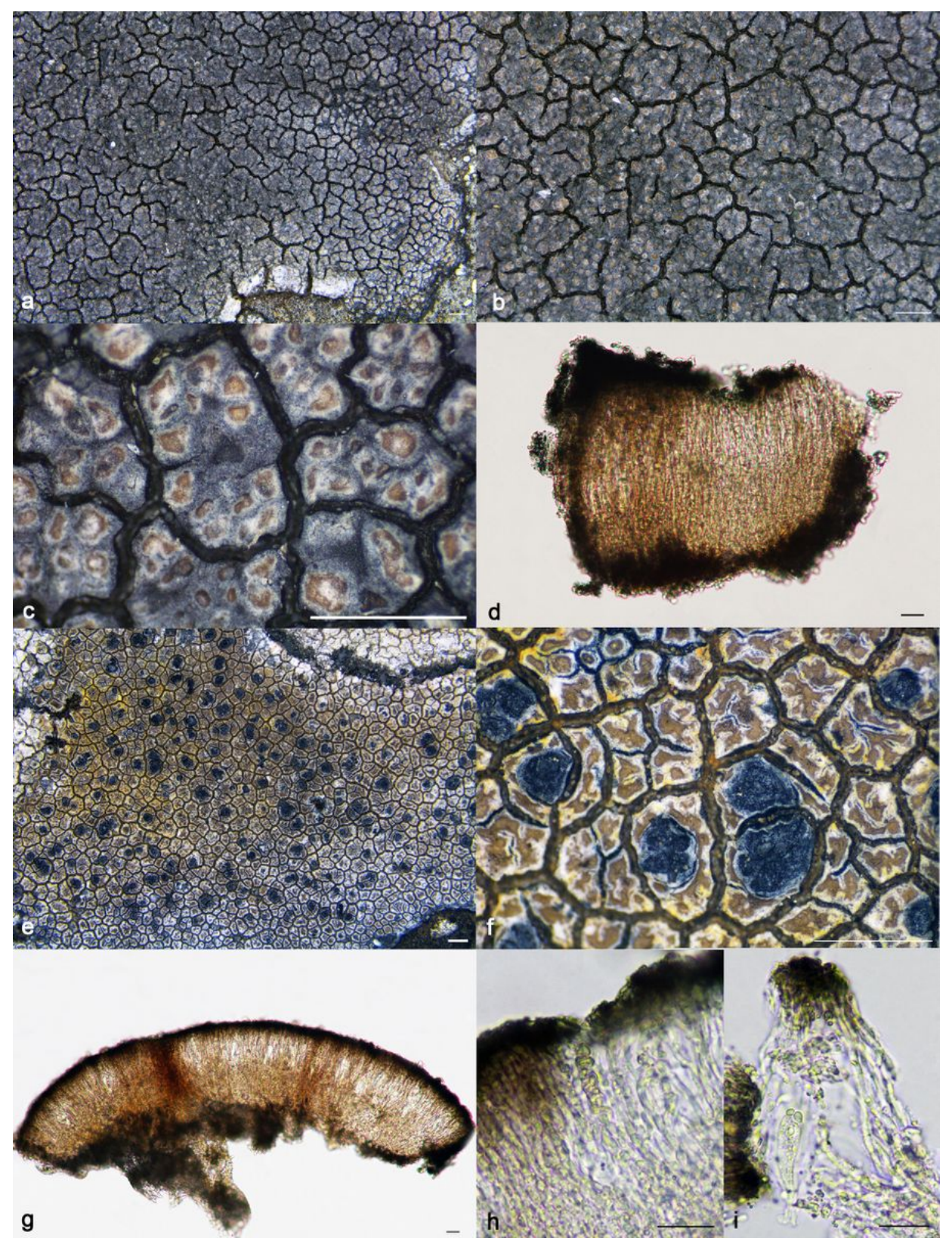

Figure 6

Immersaria shangrilaensis (a-d KUN 18-60430). a-c. Thallus; d. Apothecial anatomy. I. venusta (e-i KUN 20-66725). e-f. Thallus; g. Apothecial anatomy; h. Asci; i. Asci and paraphyses. - Scale bars: $a-c, e-f=1 \mathrm{~mm} ; \mathrm{d}, \mathrm{g}, \mathrm{h}, \mathrm{i}=20 \mu \mathrm{m}$. 


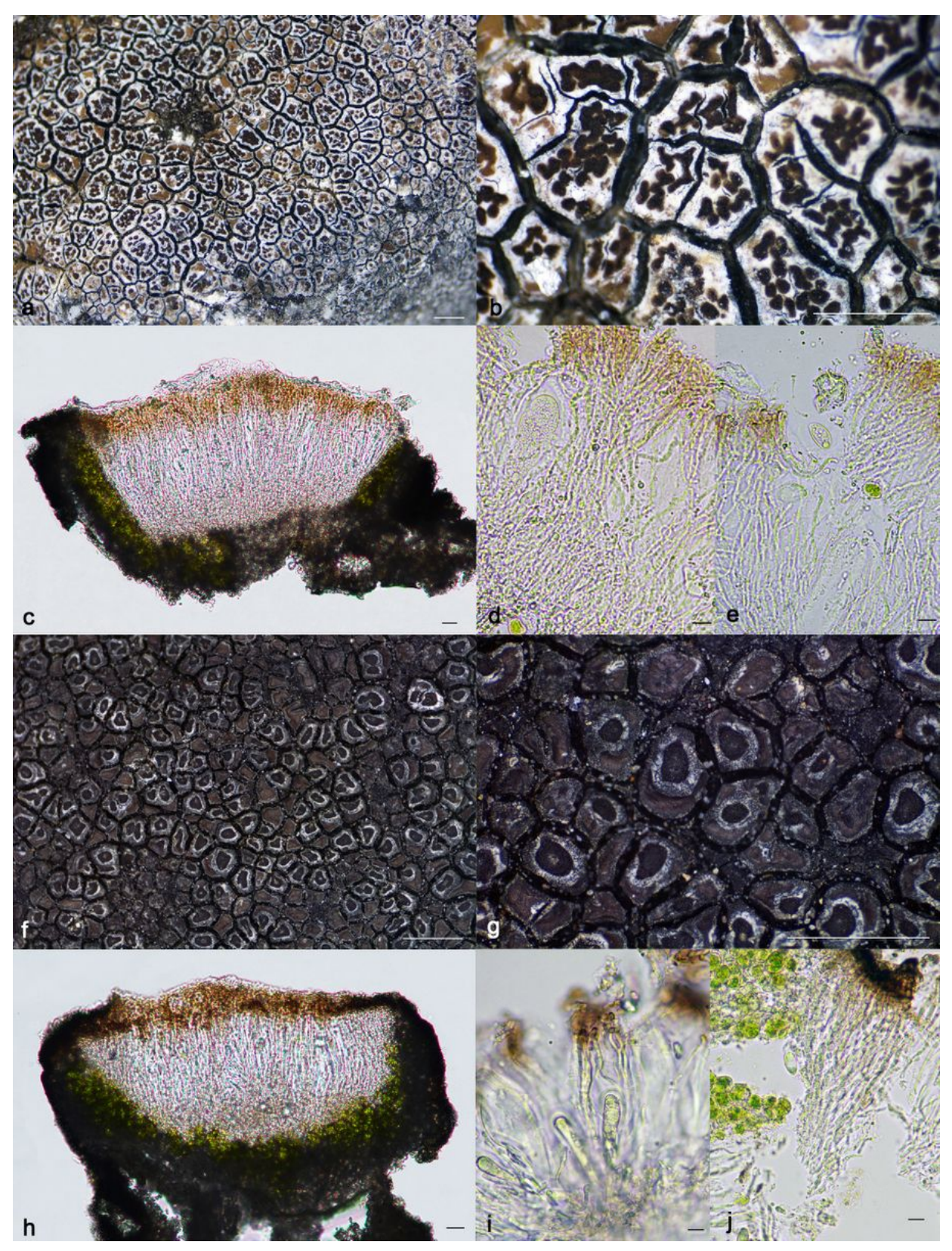

Figure 7

Lecaimmeria botryoides (a-e KUN 20-66730). a-b. Thallus; c. Apothecial anatomy; d. Asci; e. Ascospores. L. Iyagea (f-i KUN 2069070). f-g. Thallus; h. Apothecial anatomy; i. Asci; j. Ascospores. - Scale bars: $a-b, f-g=1 \mathrm{~mm} ; c, h=20 \mu m ; d, e, i, j=10 \mu m$. 


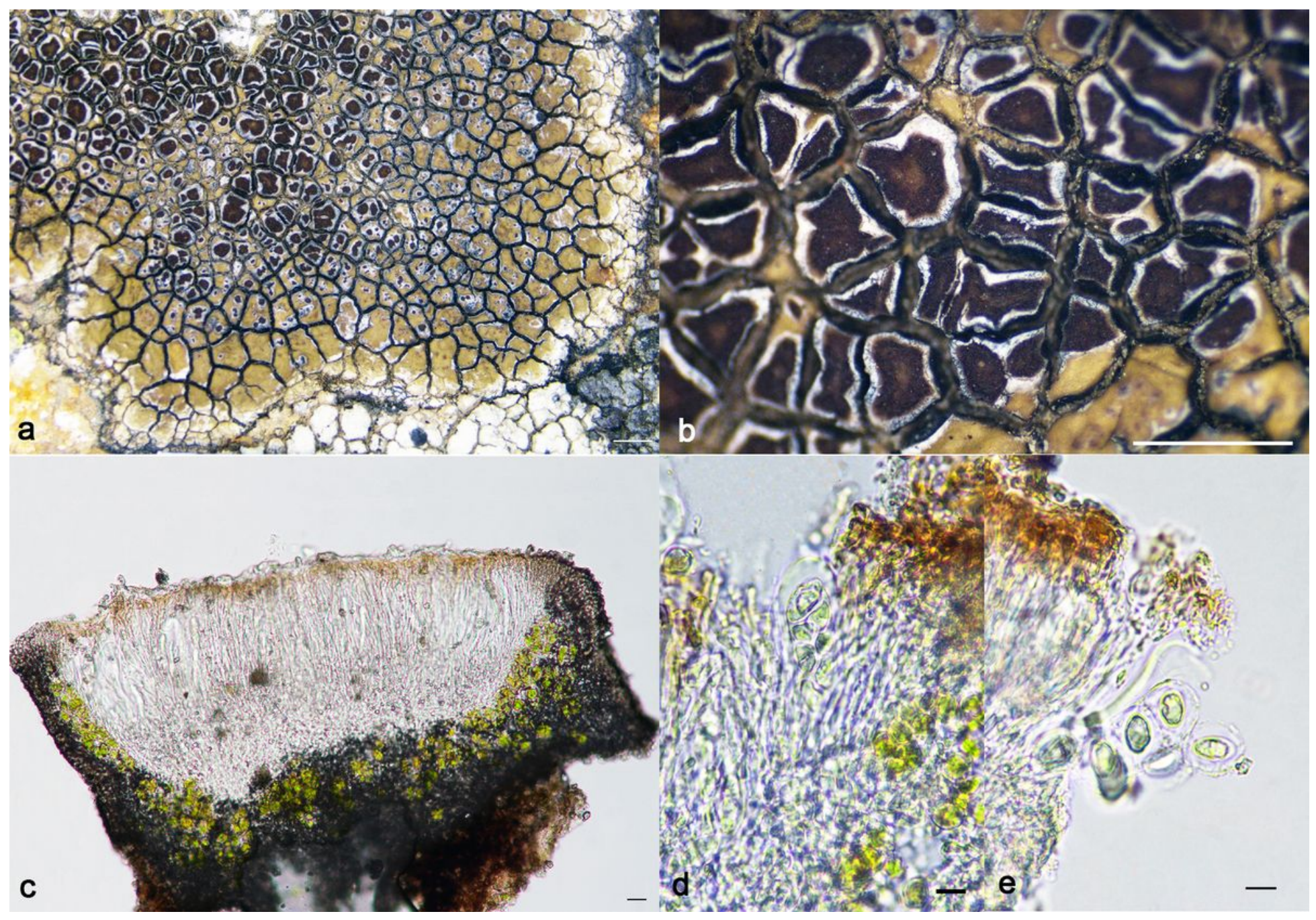

Figure 8

Lecaimmeria mongolica (a-e SDNU20190354). a-b. Thallus; c. Apothecial anatomy; d. Asci; e. Ascospores. - Scale bars: $a-b=1$ $\mathrm{mm} ; \mathrm{c}=20 \mu \mathrm{m} ; \mathrm{d}-\mathrm{e}=10 \mu \mathrm{m}$. 


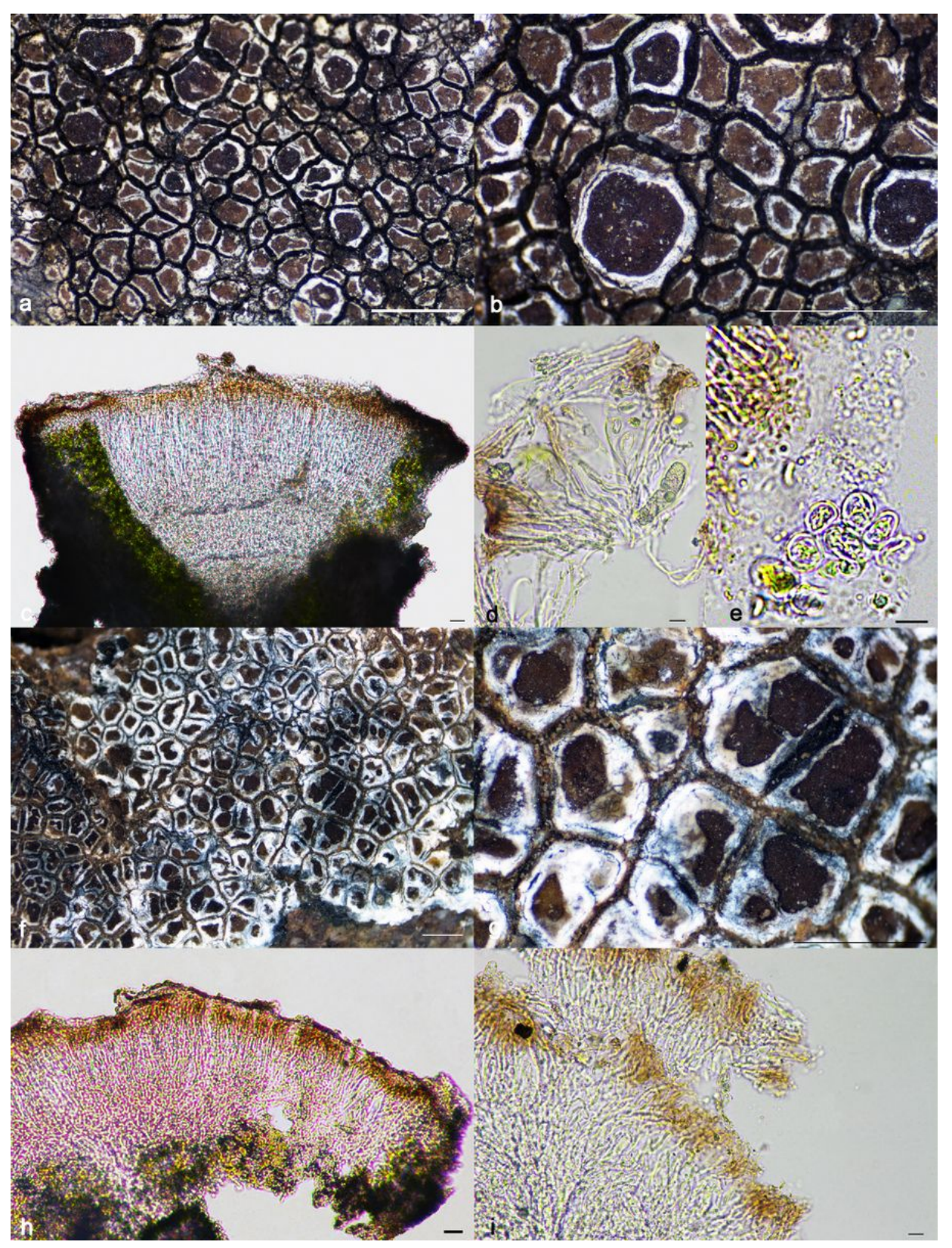

Figure 9

Lecaimmeria orbicularis (a-e KUN 20-66753). a-b. Thallus; c. Apothecial anatomy; d. Asci; e. Ascospores. L. qinghaiensis ( $f-i$ KUN 20-68696). $f-g$. Thallus; $h$. Apothecial anatomy; i. Asci.-Scale bars: $a-b, f-g=1 \mathrm{~mm} ; c, h, i=20 \mu \mathrm{m} ; \mathrm{d}, \mathrm{e}=10 \mu \mathrm{m}$. 


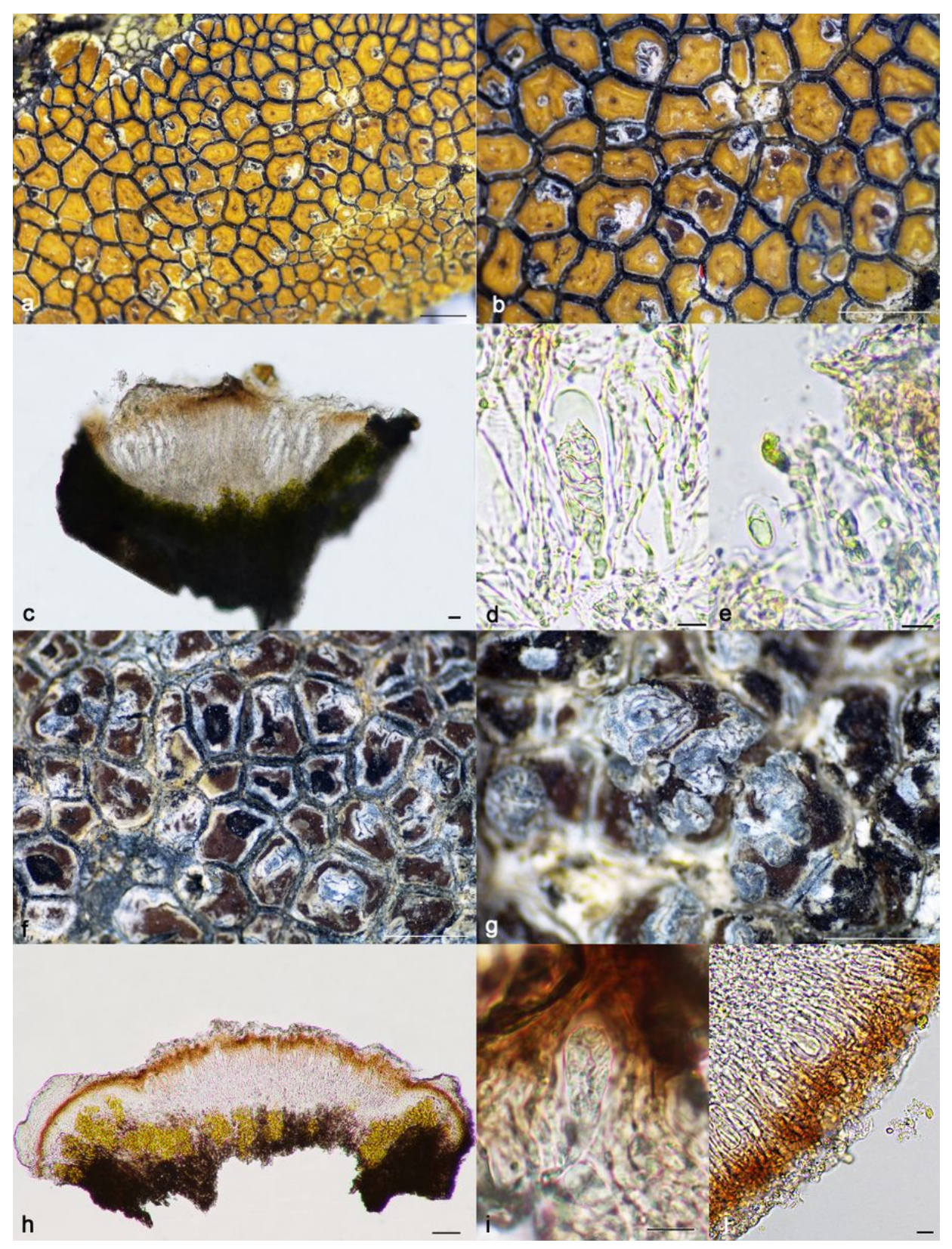

Figure 10

Lecaimmeria tibetica (a-e KUN XY19-1288). a-b. Thallus; c. Apothecial anatomy. d. Asci; e. Ascospores. L. tuberculosa ( $f-i$ KUN 18-58864). f. Thallus; g. Pycnidia; h. Apothecial anatomy; i. Asci; j. Ascopsores. - Scale bars: $a-b, f-g=1 \mathrm{~mm} ; c=20 \mu m ; d, e, i, j=$ $10 \mu \mathrm{m} ; \mathrm{h}=50 \mu \mathrm{m}$. 